\title{
معالم الوعي المنهجي في التصنيف عند ابن تيمية
}

*

محمد مصطفى الجدي

\section{الملخص}

تروم هـذه الدراسة الوقوف على حقيقة الأنماط العلميـة التي استخدمها علمـاء المسلمين في التأليف، وذلك الكماك

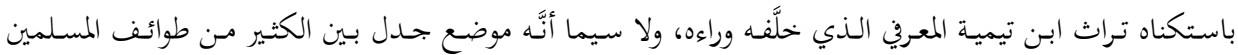

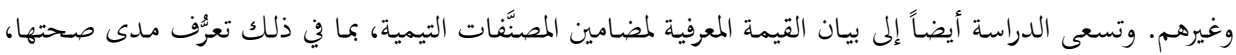

ومحاولة استكشاف منهجية التصنيف فيها عن طريق تتبع الأفكار وسياقاتما في هذه المصنَّفات.

الكلمات المفتاحية: ابن تيمية، التصنيف (الكتابة)، الوعي المنهجي، قيمة المعرفة.

\section{Hallmarks of Methodological Awareness in Ibn Taymiyyah's Writings}

\section{Abstract}

This research aims to uncover the scientific patterns used by Muslim scholars in their writings, especially the case of Ibn Taymiyyah, which received much controversy among Muslims and non-Muslims. The article attempts to illustrate the knowledge value and validity of the contents of Ibn Taymiyyah's writings, through tracing the Tayymi methodology and ideas in their contexts.

Keywords: Ibn Taymiyyah, Writing, Methodological Awareness, Knowledge value.

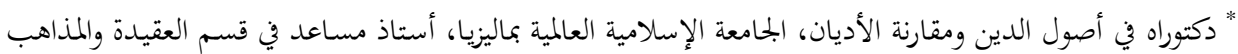

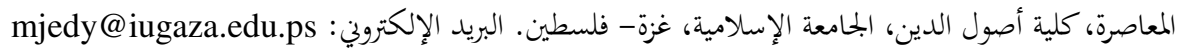

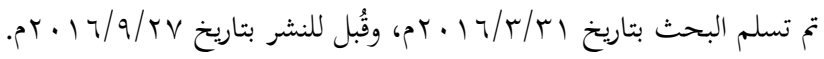




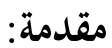

لا شـكَّ في أنَّ الالتزام بعرض الأفكار على نخوِ واضح المعالم، محلَّد الخطوات يمثّل

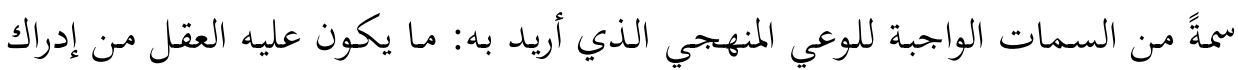

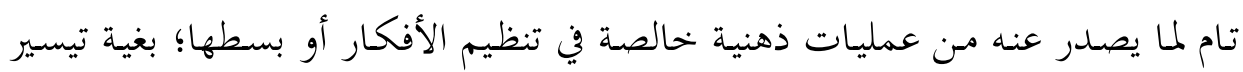

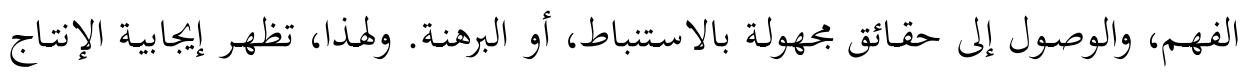

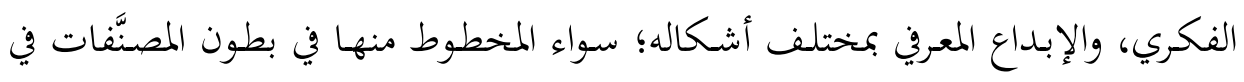

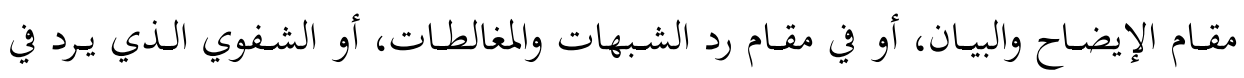

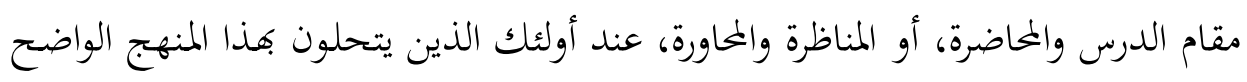

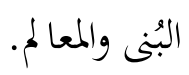

لا يخفى على كل ذي لب أثر البيئة المعرفية في تطور مصنَّفات أهل العلم والارتقاء

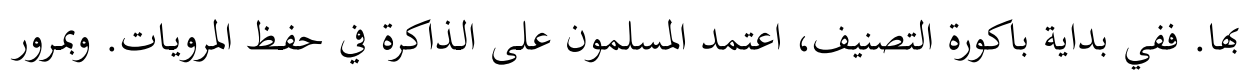

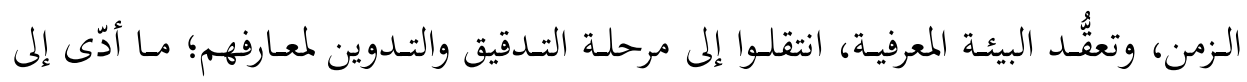

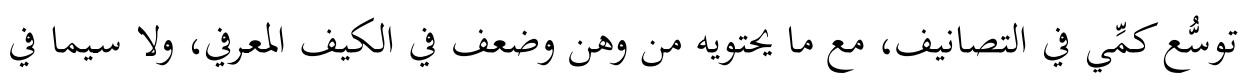

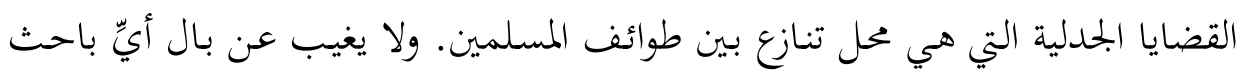

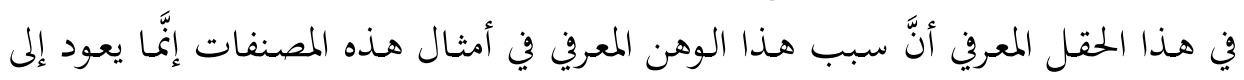

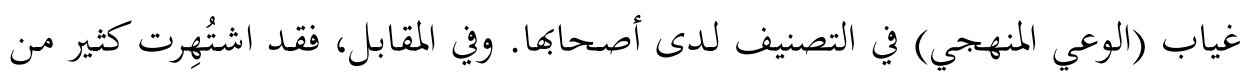

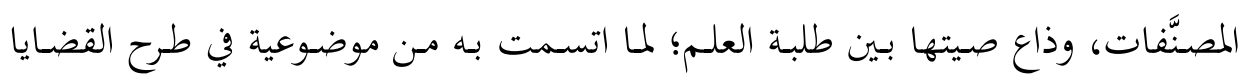
المعرفية، وحيادية في طرائق التعامل مع مواضع النزاع.

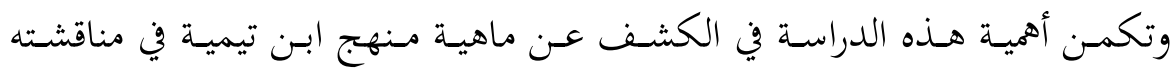

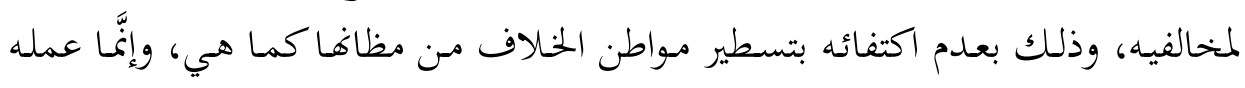

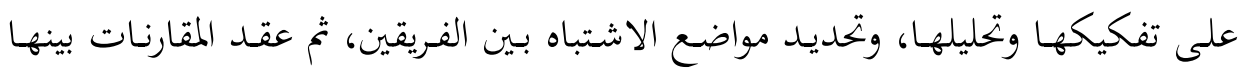

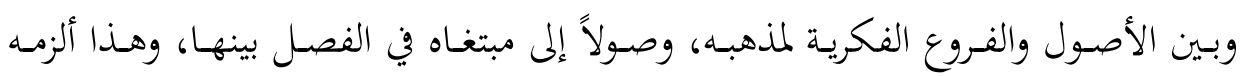

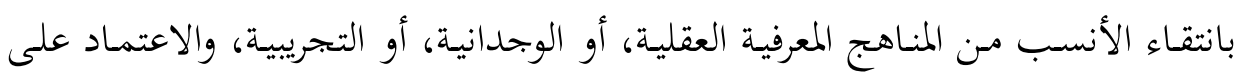

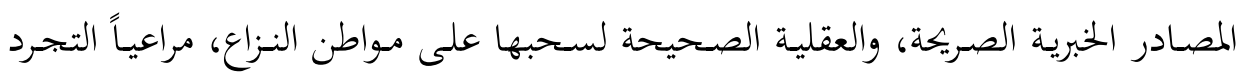


والحيادية، والوضوح والموضوعية، والأمانة والشفافية التي تظهر في مصنَّفاته، ولا سيما عند

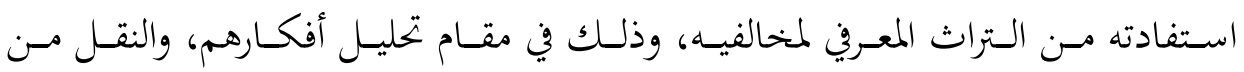
مصادرهم، والتصنيف في الرد عليهم مثلما يرى مناصروه.

ولا يغيب عن أذهاننا القيمة المعرفية في البحث عن القواعد العلمية التي قامت على

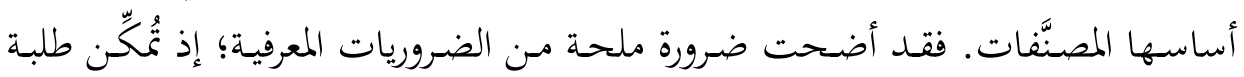

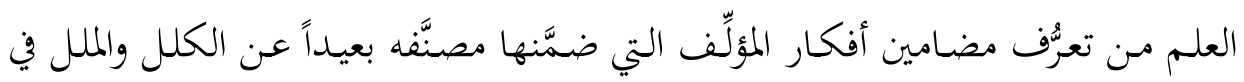

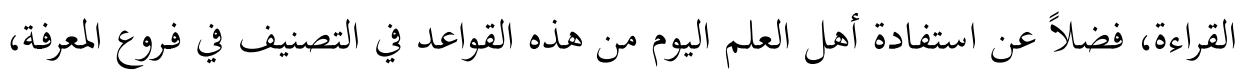

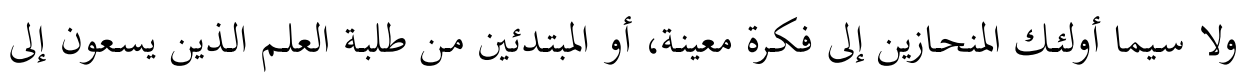

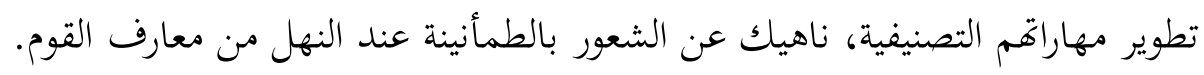
وعند إطلاق العنان للفكر في البحث عن الأسس والخصائص العلمية في مصنَّفات

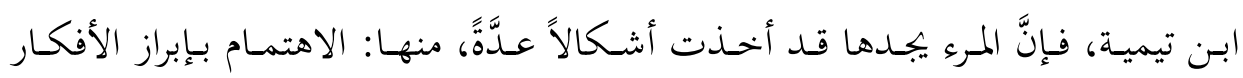
الأساسية لمذا المصنَّف، والدقة في المفاهيم، والصياغة العلمية الصحيحة، والأمانة العلمية

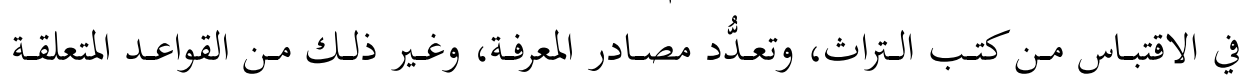
بالمصادر العلمية وطريقة الكتابة، التي سنعرض لها في في ثنايا هذا البحث.

وبعد هذه التوطئة يستبين مقصد الدراسة، وهو بيان أحد أشكال الوعي المنهجي في مصنَّفات ابن تيمية، وذلك ببيان طريقته في التأليف التي عُرِف بها بين أطنابه، فضلاًَ عن ولن محاولة الكشف عن أخطائه في التصنيف حال تعرُّفا. تقتضي طبيعة موضوع الدراسة تقسيمها إلى مقدمة، ومحورين، وخمسة أفرع، وخاتمة؛

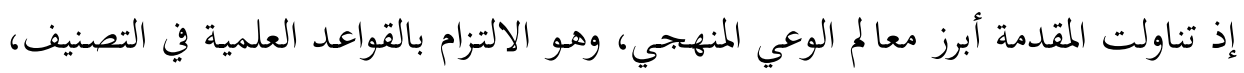

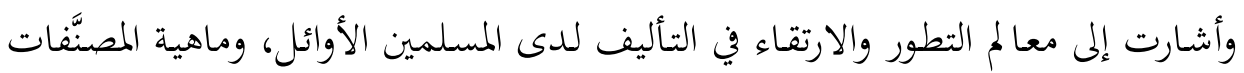
المعتبرة لدى طلاب العلم، فضلاً عن التذكير بحدود الدراسة، وذكر بعض ملامح منهج ابن تيمية في مصنَّفاته. وأمَّا جوهر الدراسة فقد ارتكز على محورين اثنين؛ الأول: مقومات المنهج البحثي الإجرائي التيمي في التصنيف، وتشمل: الأمانة العلمية في النقل والتوثيق، وحصر الأقوال في مسائل النزاع. والمحور الثاني: دعائم المنهج البحثي الموضوعي التيمي في وتئي 


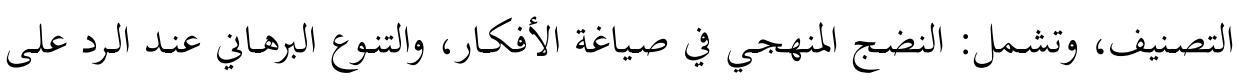

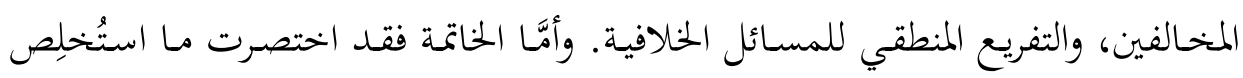

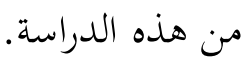

\section{أولاً: مقومات المنهج البحثي الإجرائي التيميّ في التصنيف}

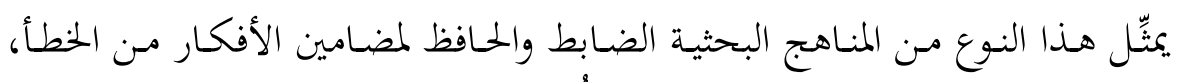

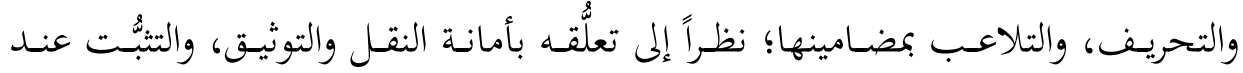

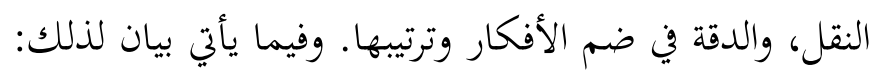

\section{ا ـ الأمانة العلمية في النقل والتوثيق:}

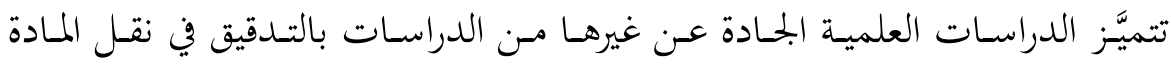

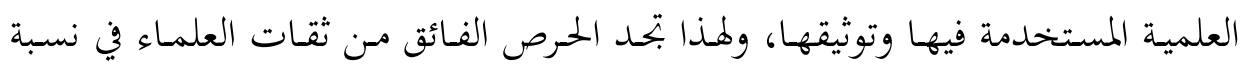

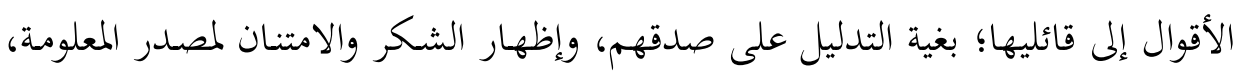

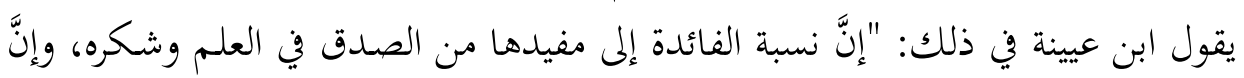

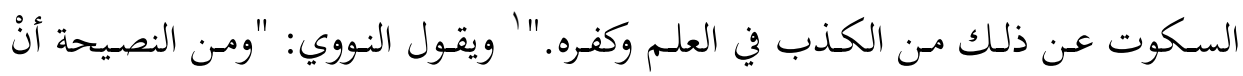

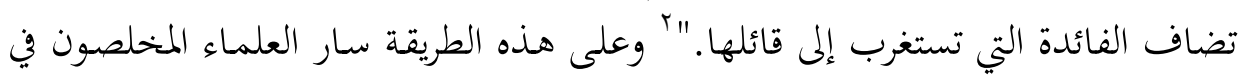

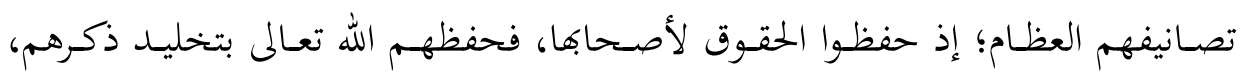
ونشر علمهم في الآفاق، وتسخير أهل العلم للدفاع عنهم عبر الأزمان.

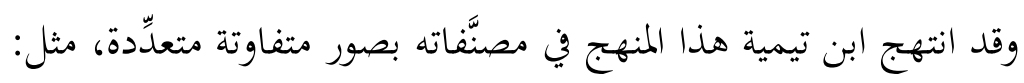

\section{أ. مطابقة النقل للنص، والتحذير من اللوازم الفاسدة:}

فنقـل النصـوص مـن كتـب الآخـرين هـو مـن العـادات الدارجـة بـين المصنِّفين قـديماً

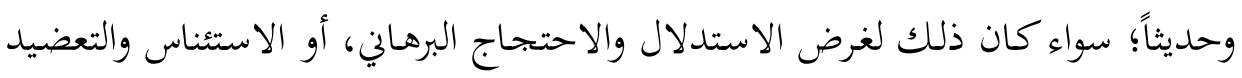

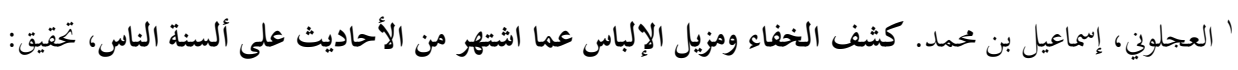

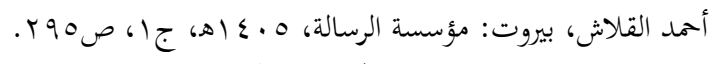

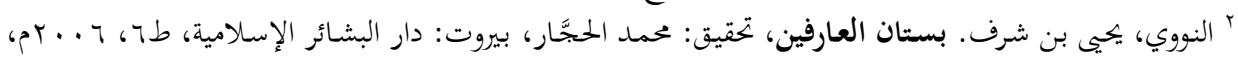


للأفكار، أو حتى بلمرد الإمتاع الذهني؛ ولم يخالف ابن تيمية في ذلك، وهذا ما سيتم بيانه

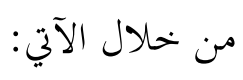

\section{- أنواع النقل عند التصنيف:}

تُصنَّف النصوص المنقولة إلى نوعين؛ الأول: النقل الحرفي للنص، وذلك بإيراده مـن

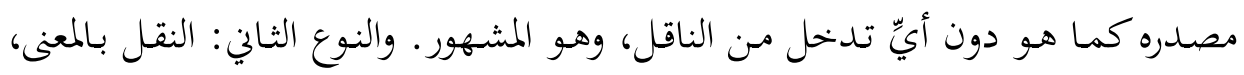

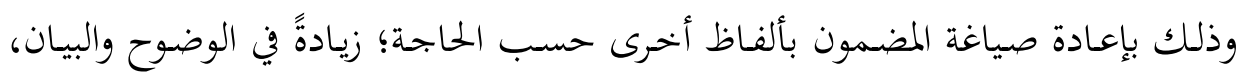

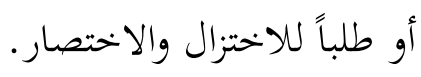

ولا يُعَدُُّ نقـل النصـوص الحـرفي موضـع استشـكال على الأغلـب؛ وذلكك لسـهولة

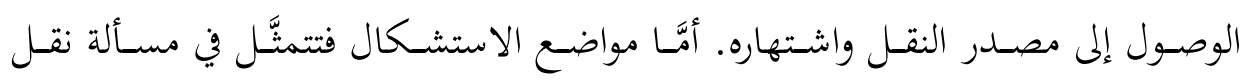
النصوص بالمعنى، ولا سيما إذا كثر حولها اللغط، وكانت موضع خلاف بوان بين المتنازعين. وقد صرَّح ابن تيمية بشيء من منهجيته في نقل النصوص وتوثيقها بقوله: "ونحن في جميع ما نورده نخكي ألفاظ المحتجين بعينها، فإن التصرف في ذلك قد يدخله خروج عن من فئن

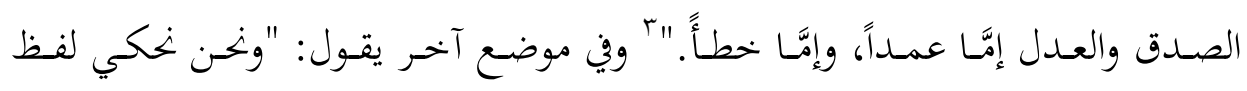

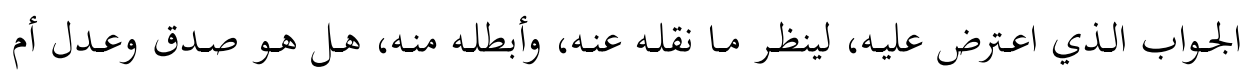
لا؟" وكان هذا في معرض رده على مَن أخطأ في النقل انتصاراً لرأيه من الذين لم يقدروا

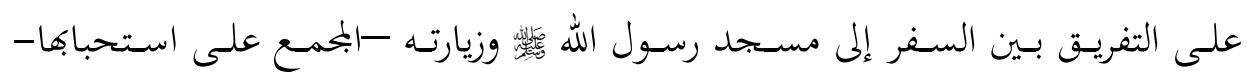
والسفر إلى زيارة قبر غيره.

وعند التدقيق في النصوص التي أوردها ابن تيمية في مصنَّفاته، بجدها على نوعين؛

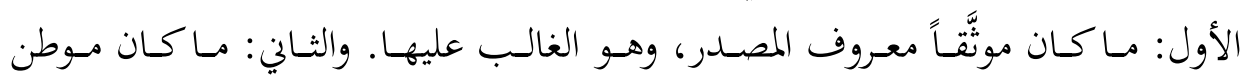

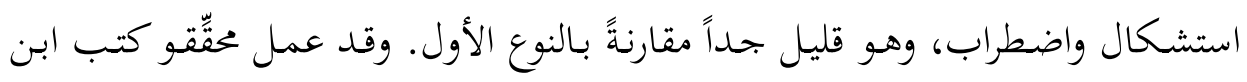

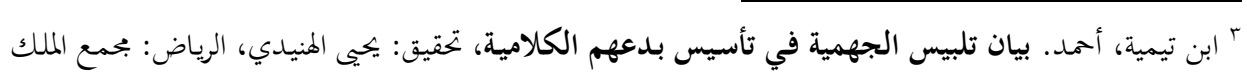

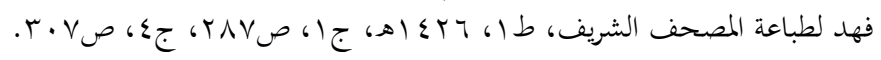

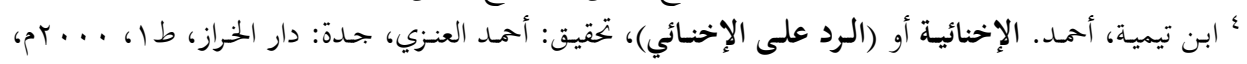


تيمية على إزالة أوجحه الغموض عنها، بالكشف عن ماهية نصوصها، مثل تحديد مظاها

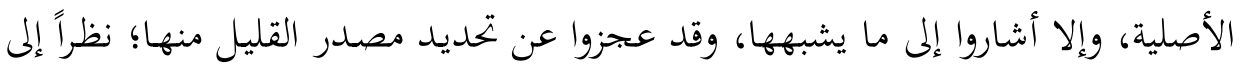

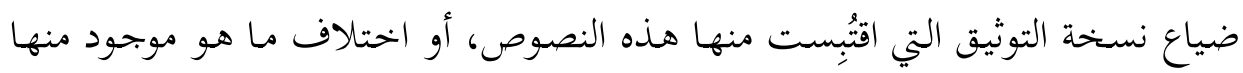
الآن عن الذي نَقل منه المؤلِّف.

\section{- طبيعة النصوص المنقولة في المصنَّفات التيمية:}

إنَّ المتتبِّع للنصوص المنقولة التي أوردها ابن تيمية في مصنَّفاته يلحظ أنَّ غالبيتها قد

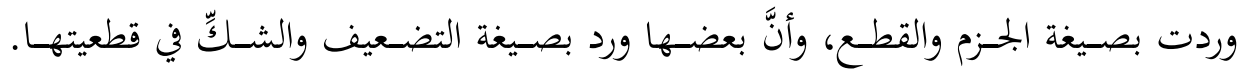
فمثلاً، عندما أراد ابن تيمية أن يستدل على وردي وان عظم الشر المترتب على فساد أهل الرياسة

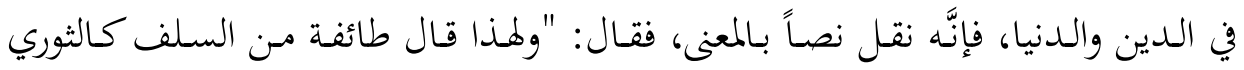

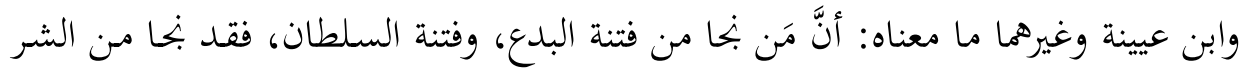

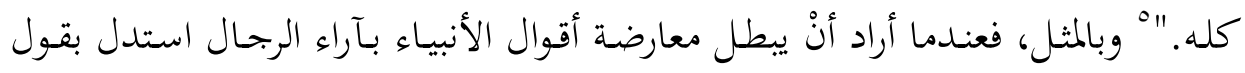

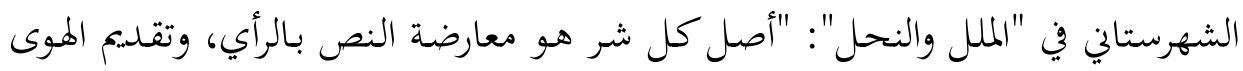

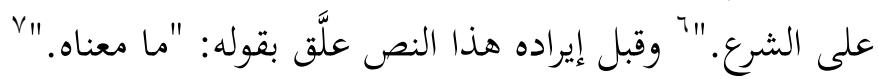

\section{- منهج تعامل ابن تيمية مع النصوص المنقولة:}

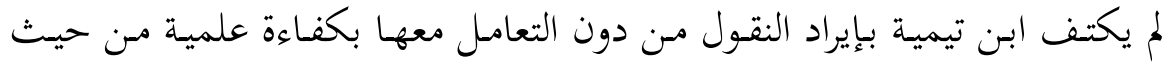

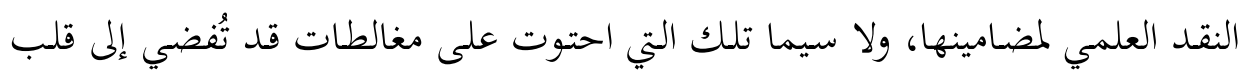

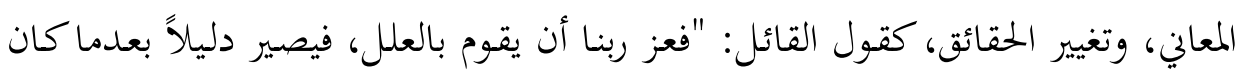

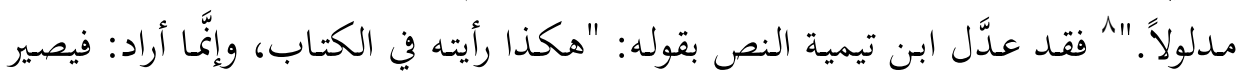

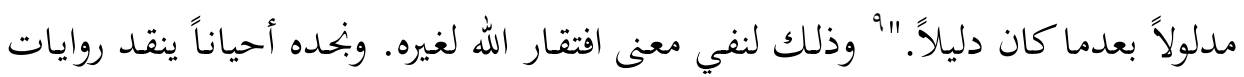

• ابن تيمية، أحمد. مجموع الفتاوى، تحقيق: عبد الرحمن بن قاسم، المدينة النبوية: بحمع الملك فهد لطباعة المصحف

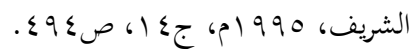

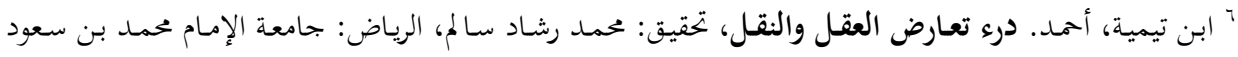

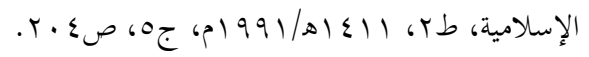

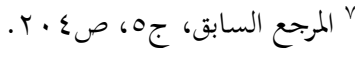

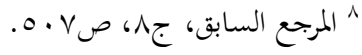

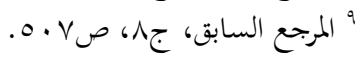




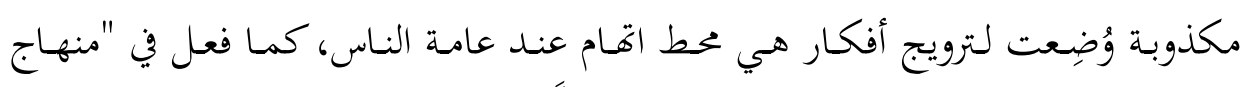

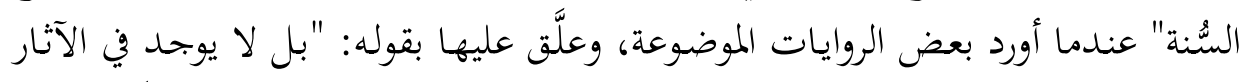

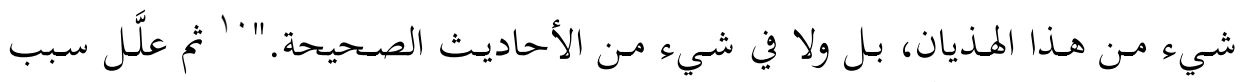

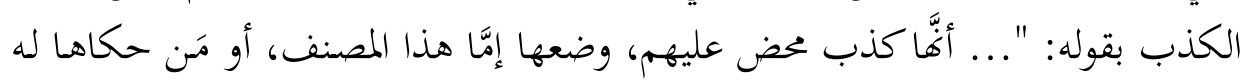

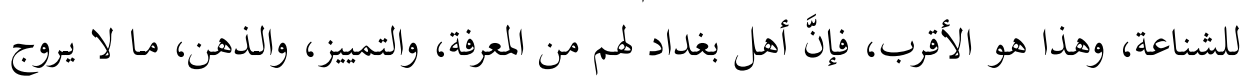

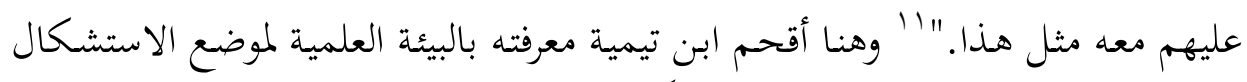

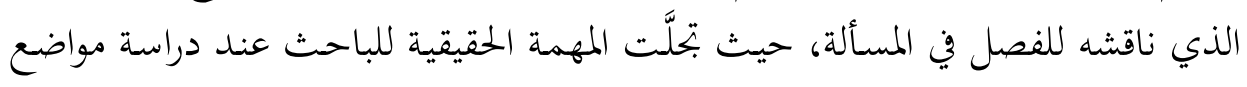

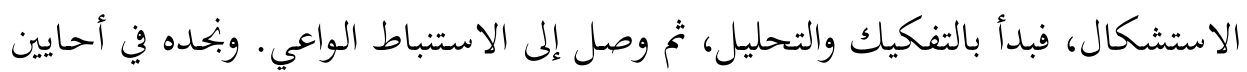

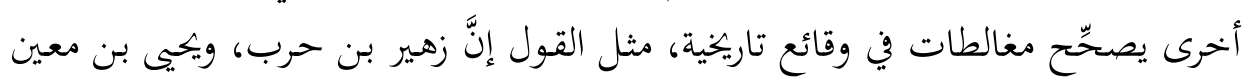

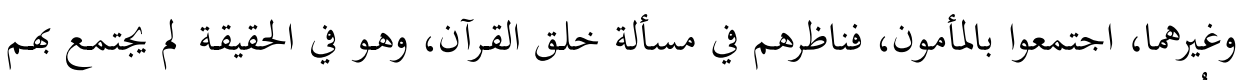
قصل

\section{ب. تحديد مواضع النقل، والتثبُّت منها:}

من اللافت للنظر في مصنَّفات المسلمين المعتبرة، اهتمامهم ببيان المصادر المعرفية

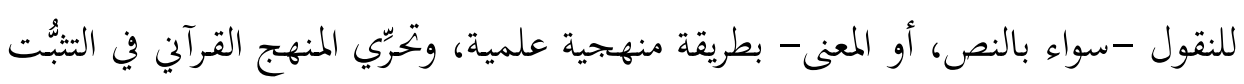

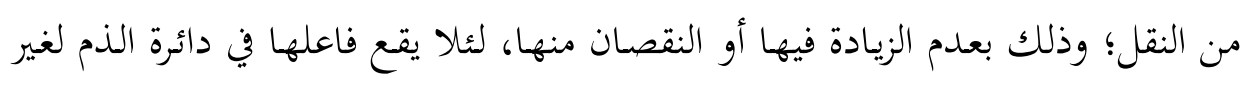

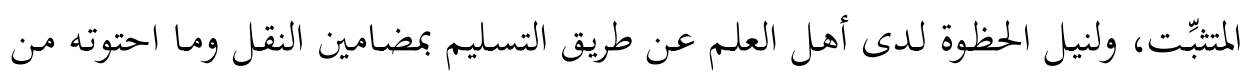

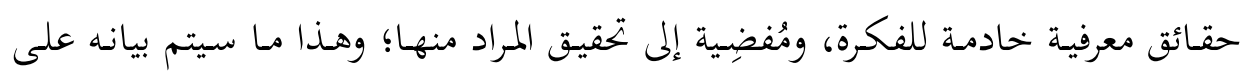

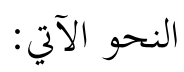

\section{- تعدُّد مصادره والهدف منها:}

للكشف عن فاعلية هذا المنهج في مصنَّفات ابن تيمية، يجب التجرُّد من الأحكام

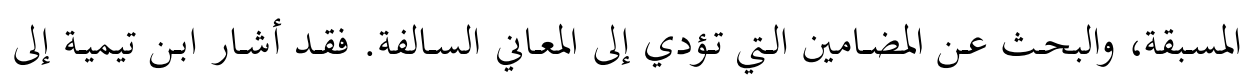

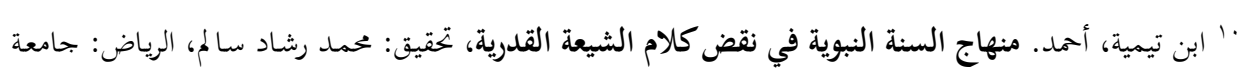

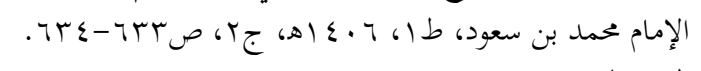

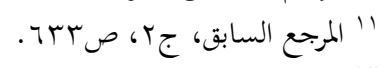

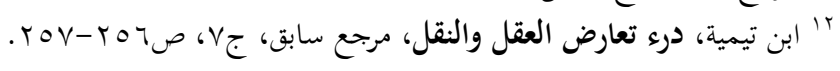




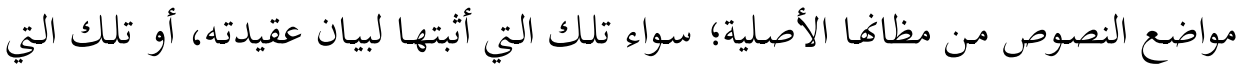

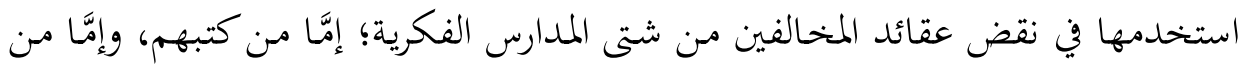
كتب غيرهم.

والذي ساعد ابن تيمية على توثيقه العلمي للمصادر التي استخدمها في تأليفه، هو

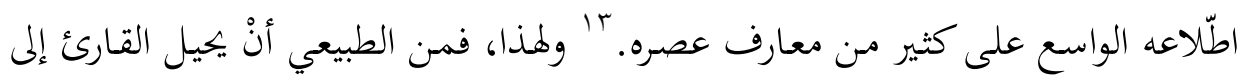

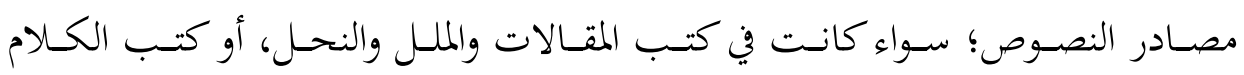

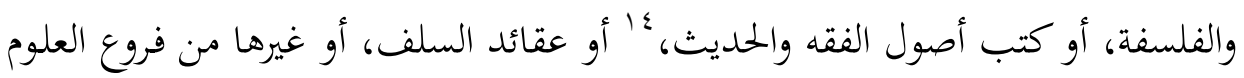
الأخرى.

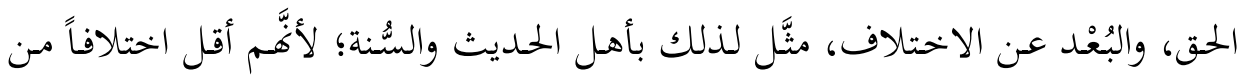

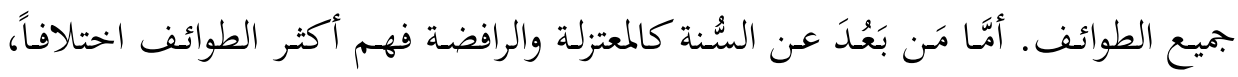

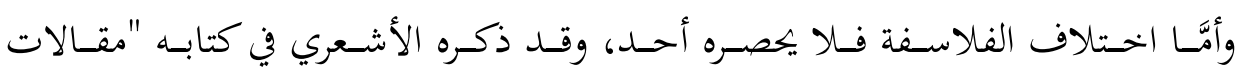

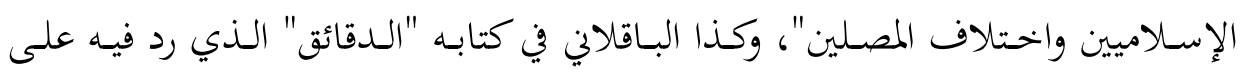

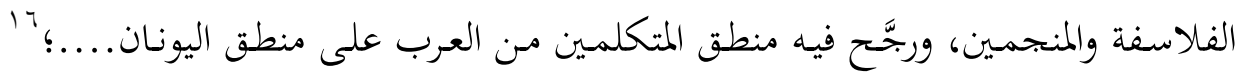

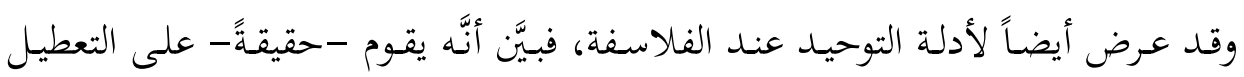

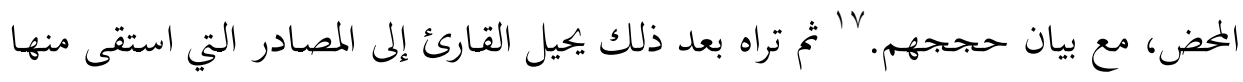

"ا البزار، عمر بن علي. الأعلام العلية في مناقب شيخ الإسلام ابن تيمية، تحقيق: صلاح الدين المنجد، بيروت:

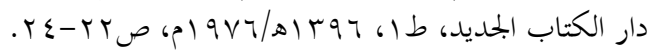

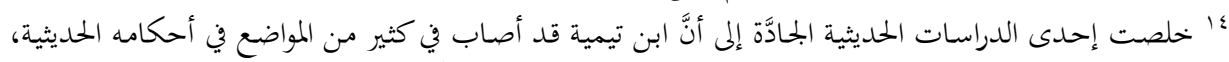

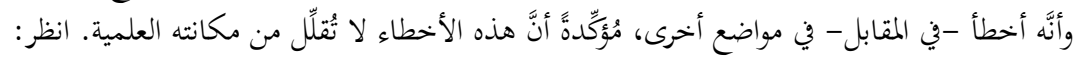

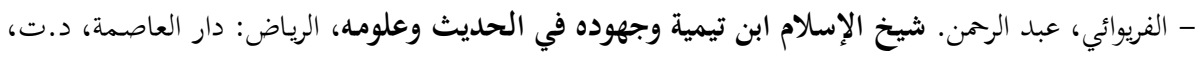

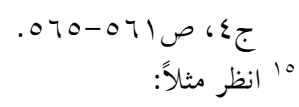

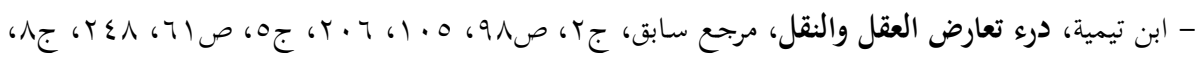

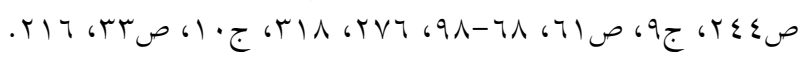

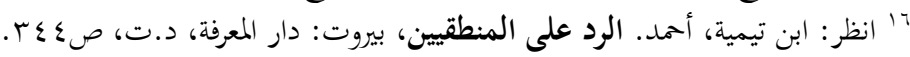

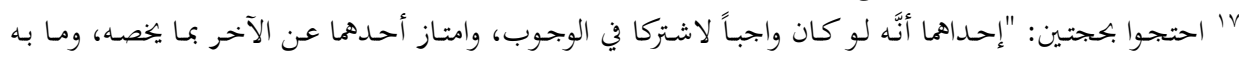

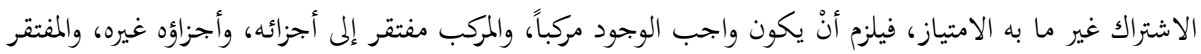

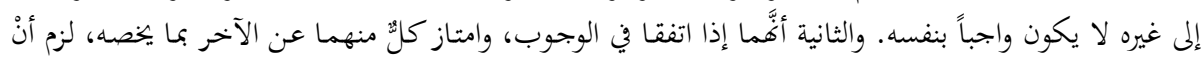


حُكمه، قائلاً: "وهذا ملخص ما ذكره ابن سينا في إشاراته، هو وشارحو (الإشارات) ك:

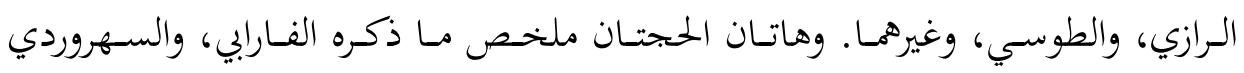

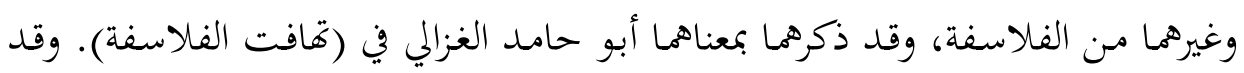

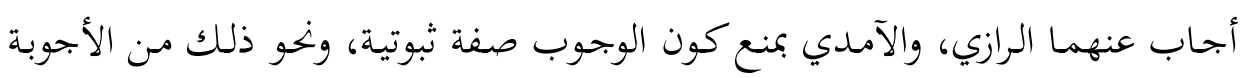

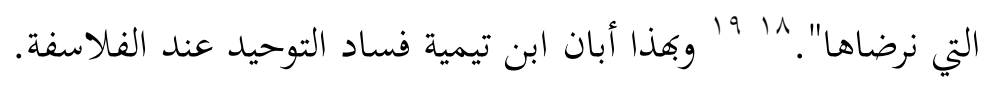
يُذكَر أنَّ ابن تيمية اهتم بـالتنويع في النصوص والمصادر؛ سواء المنتمية إلى مدرسة

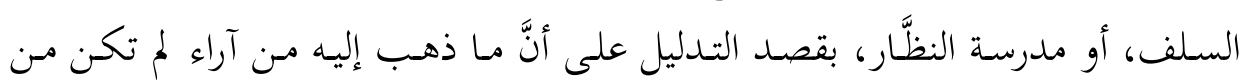

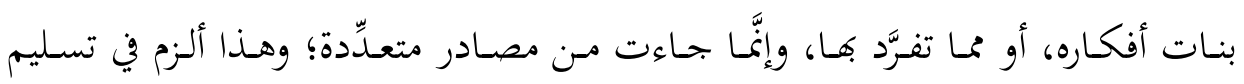
المخالف، وأدعى في النزول إلى قول المحاجج، فليتنبه لذلك أهل العلم في هذا الزمان.

\section{- طريقته في التثبت والتدقيق:}

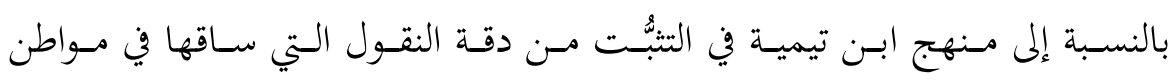

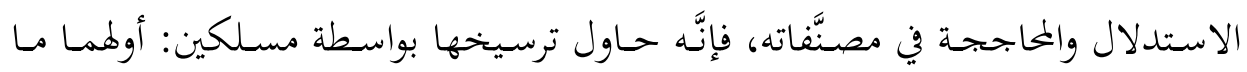

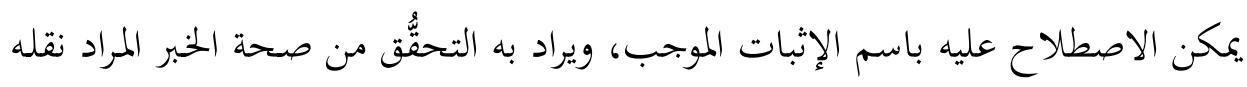

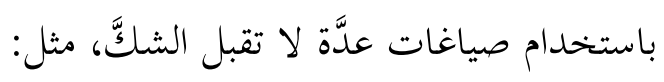

اعتماد الإسناد المتصل وأقوال الثقات في الاستدلال. فلمَّا أراد ابن تيمية بيان

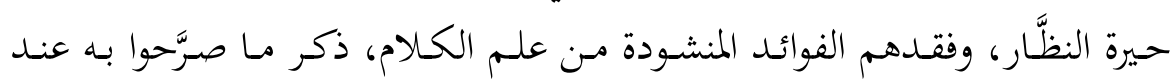

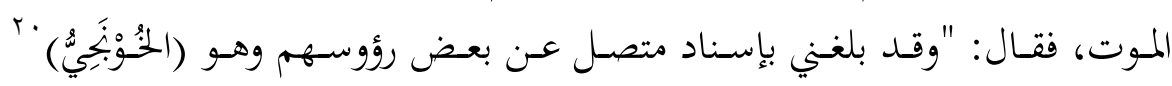

يكون المشترك معلولاً للمختص، كما إذا اشترك اثنان في الإنسانية، وامتاز كلٌٌ منهما عن الآخر بشخصه، فالمشترك

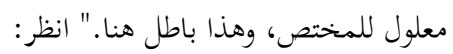

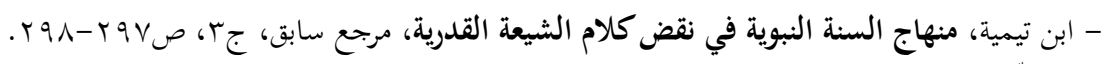

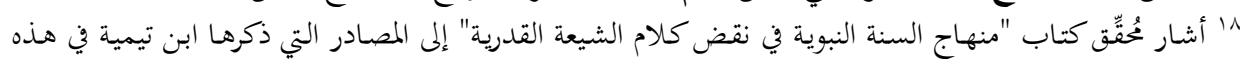

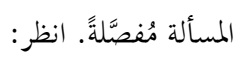

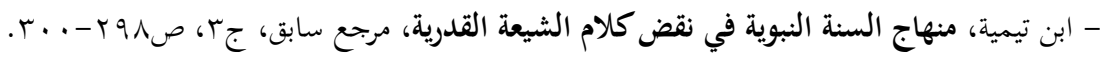

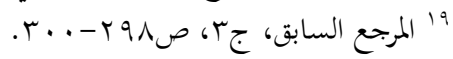

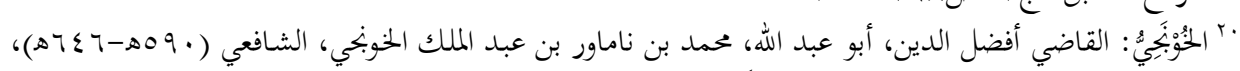

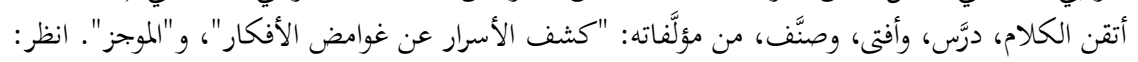




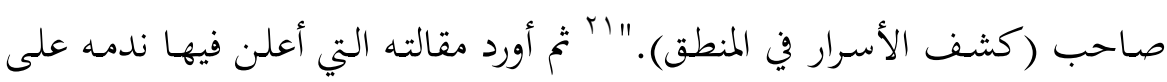

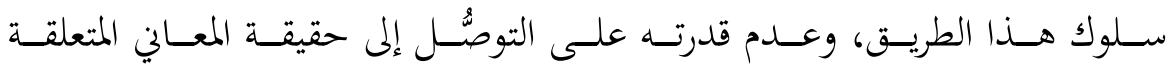

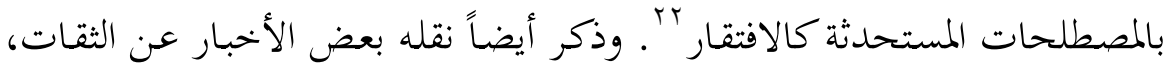

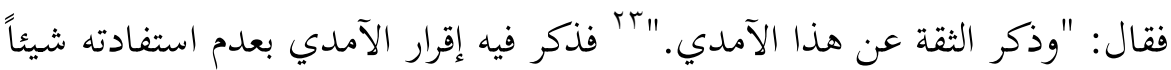

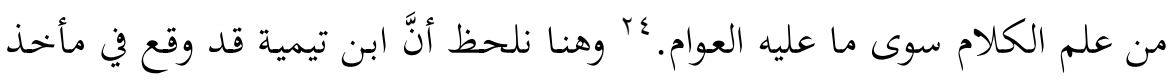

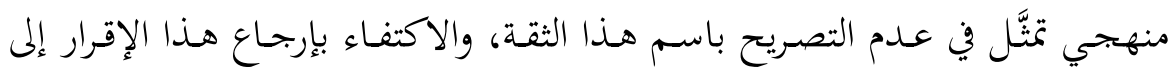

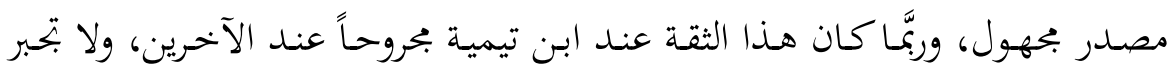
روايته.

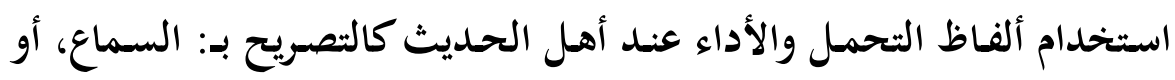

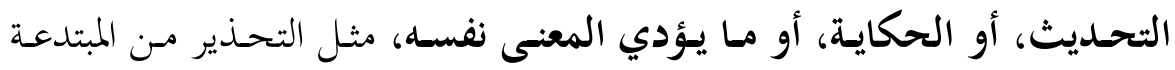

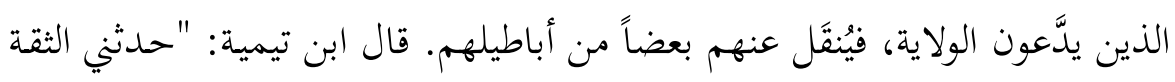

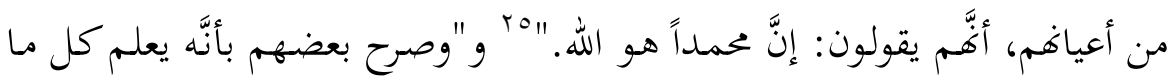

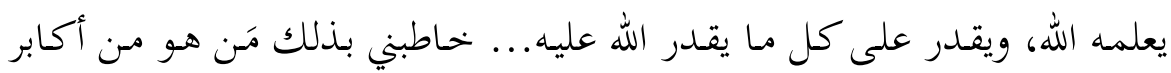

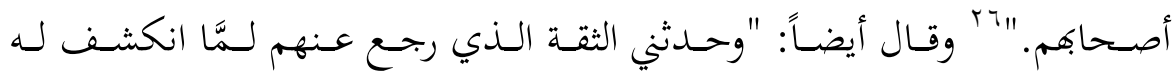

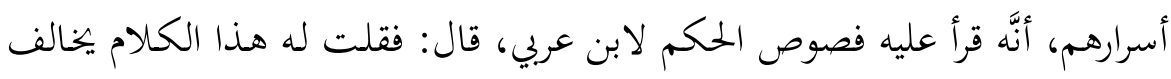

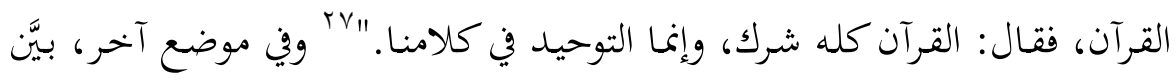
- ابن كثير، إسماعيل. البداية والنهاية، تحقيق: عبد الله التركي، مصر : هجر للطباعة والنشر، طا، لو9 19 1م،

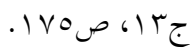
- الصفدي، خليل بن أيبك. الوافي بالوفيات، تحقيق: أحمد الأرناؤوط، بيروت: دار إحياء التراث، ... Fم،

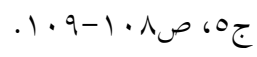

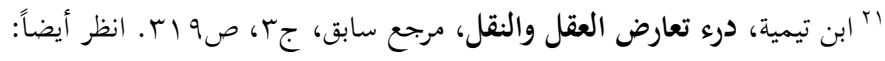

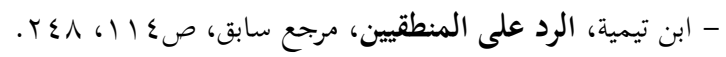

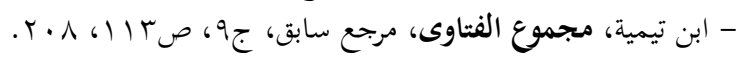

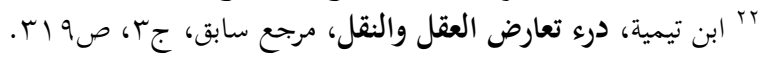

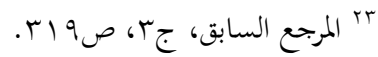

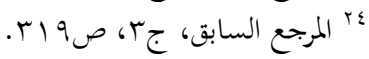

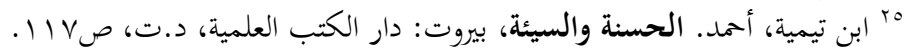

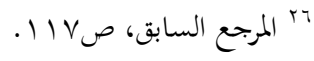

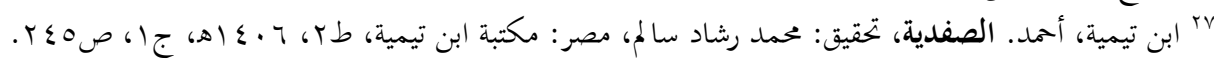




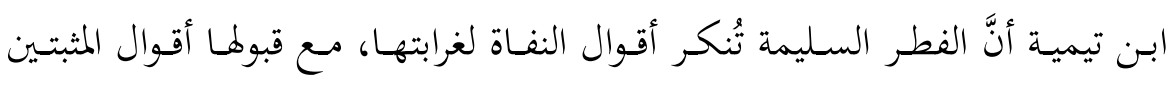

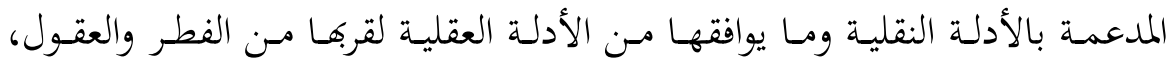

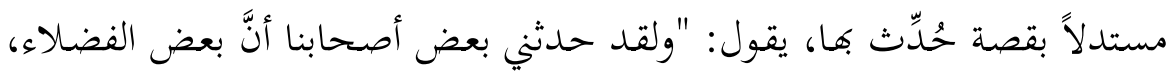

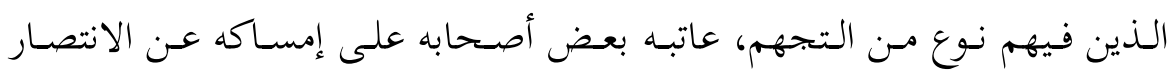

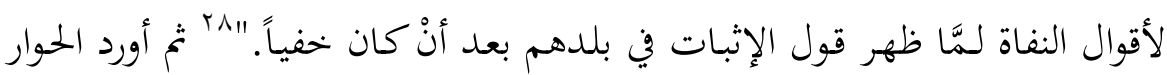

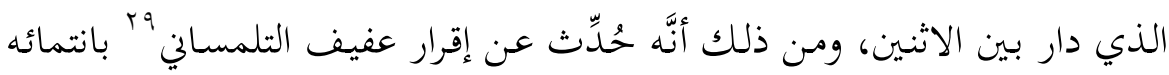

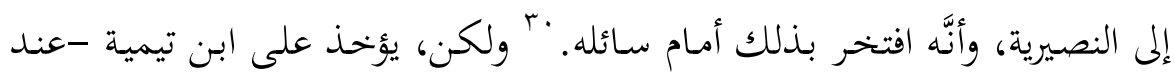

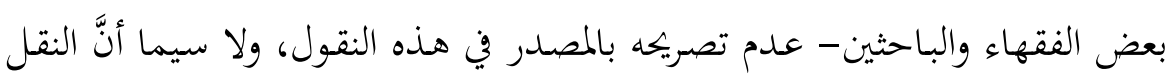

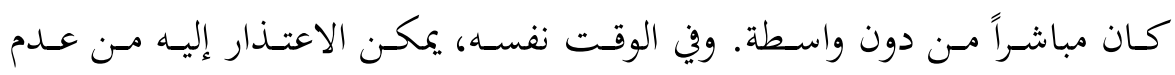

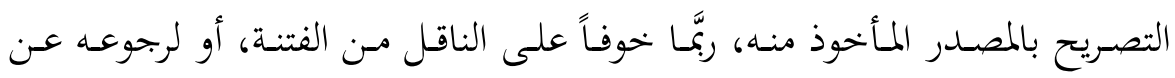
المذهب الفاسد، وهذا من باب الستر.

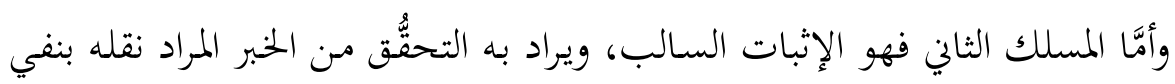

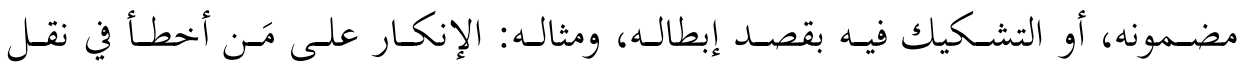

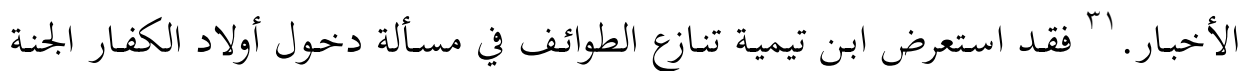

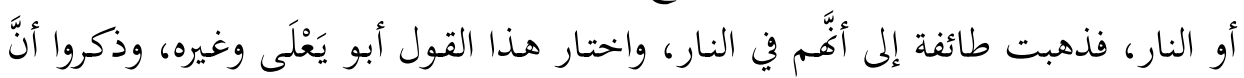

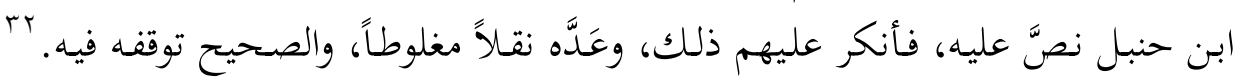

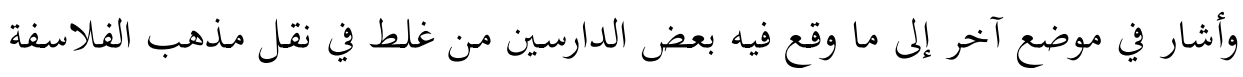

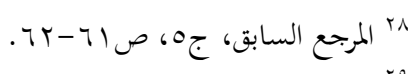

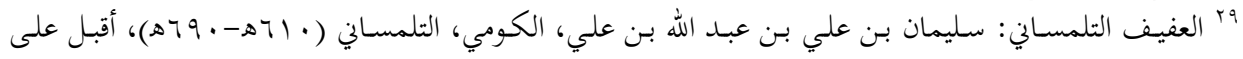

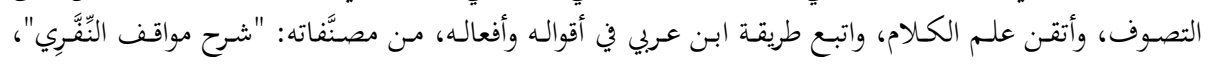

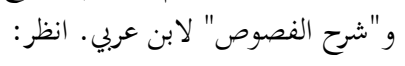

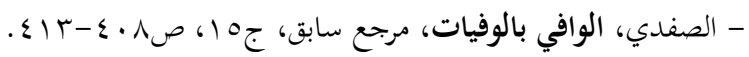

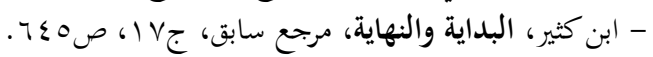

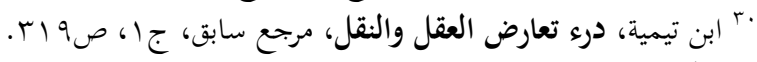

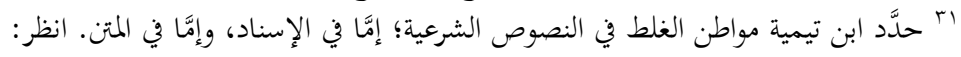

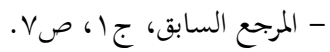

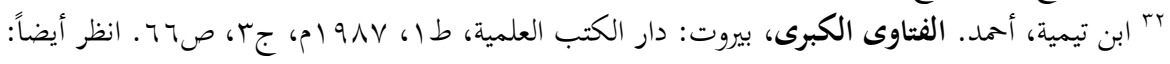

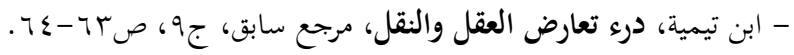

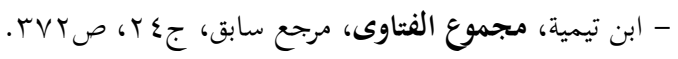




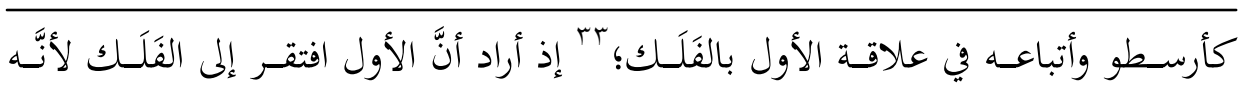
يتحرك للتشبه به، لا لكون الأول علة فاعلة له، أو غيرها من المغالطات.

\section{ت. دواعي الوقوع في الفلط عند الآخرين:}

بعد استقراء النصوص التي أشـار فيها ابن تيمية إلى مواطن الغلط، يمكن تلخيص مسبِّباتها فيما يأتي: - اعتماد المستخلصات الفكرية المغلوطة، ثم حكايتها من طائفة أخرى حتى تصبح

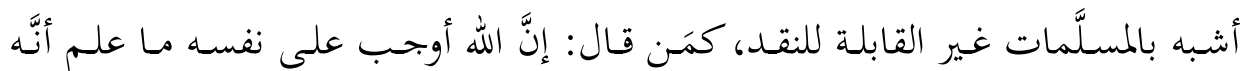
سيفعله، مب وهذا مخالف لما عليه جمهور أهل السُنة والجماعة.

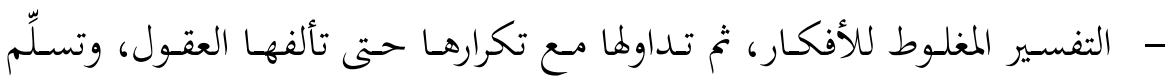
بصحتها، ولا سيما إذا وردت من جهة أهل العلم، ومثاله: عندما حكى الرازي بَّ بعبارته

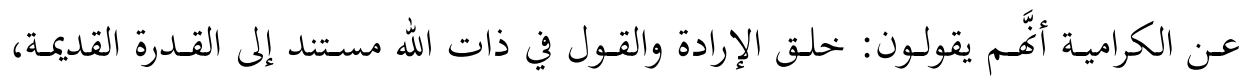
وخلق ما في المخلوقات مستند إلى الإرادة والقول؛ فإنَّ ابن تيمية اعترض على نسبة هذا

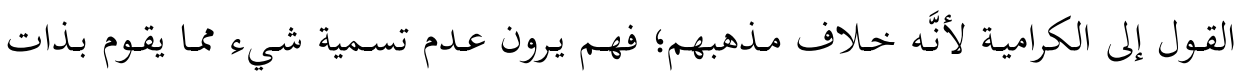

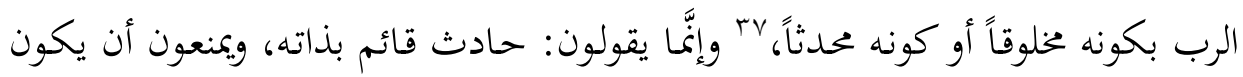

rrr الفَلَك: جسم كروي يحيط به سطحان: ظاهري، وباطني، وهما متوازيان، ومركزهما واحد. انظر:

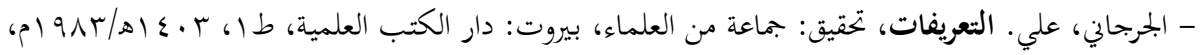
ص ص إن

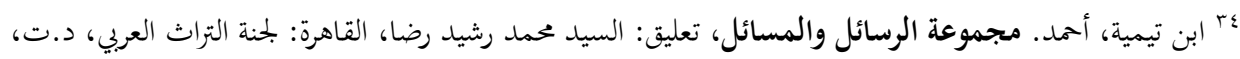

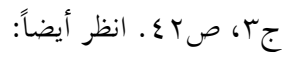

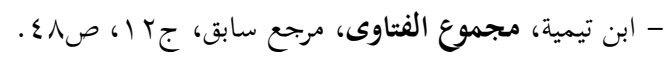
ro

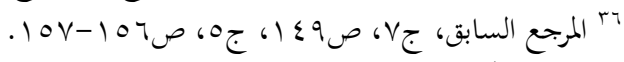

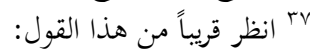

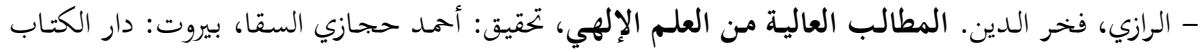

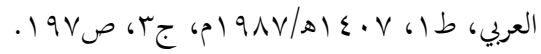

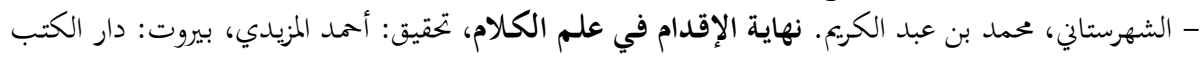


في الأزل كلام؛ لأنَّ ذلك يقتضي حوادث لا أول لها، أو يقتضي قِدم القول المعين؛ وكلا

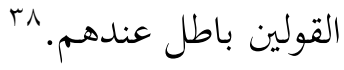
- - نسبة الأقوال غير الصحيحة إلى العلماء، ثم تناقُلها بوصفها أقوالاً صحيحةً،

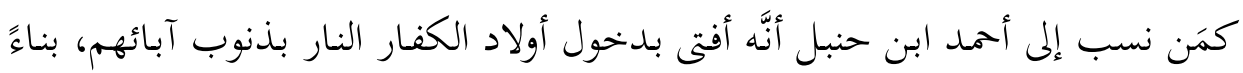

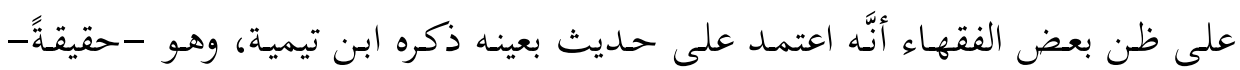
موضوع لم يعتمد عليه في فتواه.

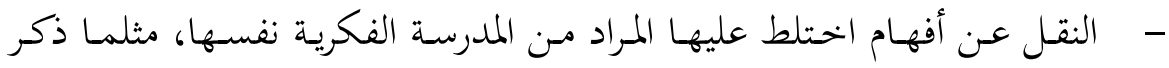

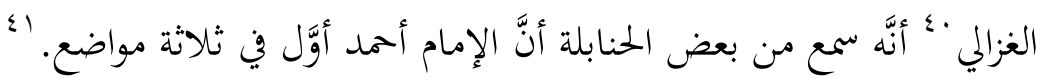

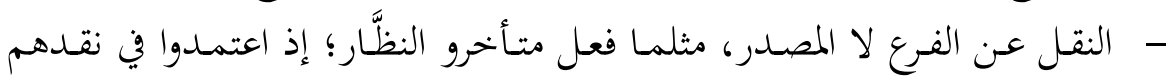

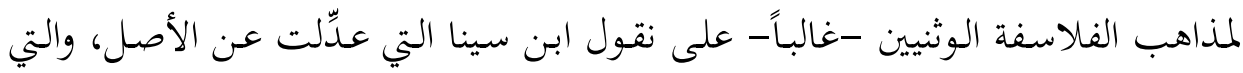

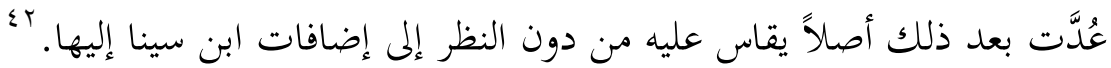

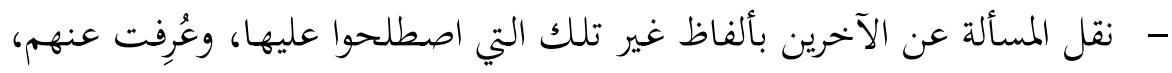

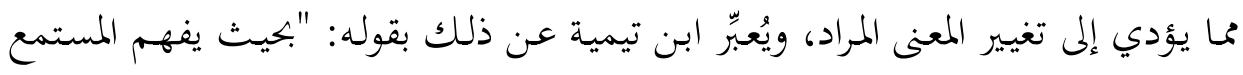

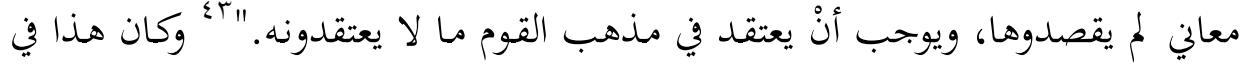

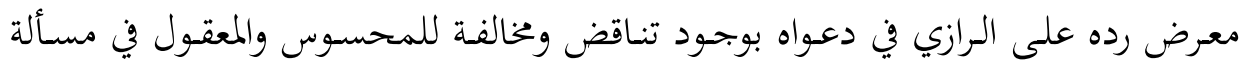

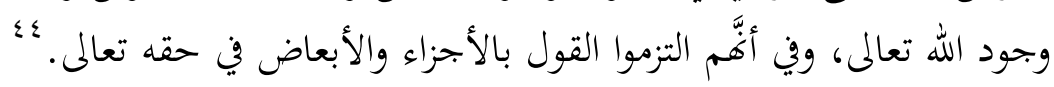

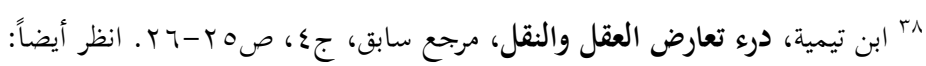

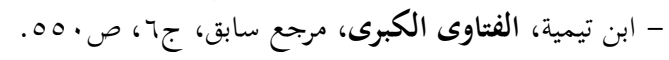

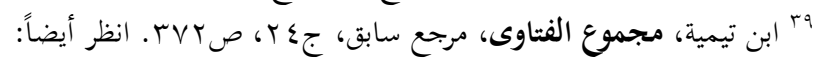

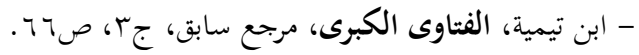
•؛ الغزالي، أبو حامد. فيصل الثفرقة بين الإسلام والزندقة، تعليق: عمود بيجو، دمشق: دار البيروني، طا،

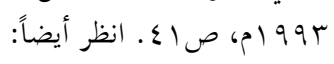

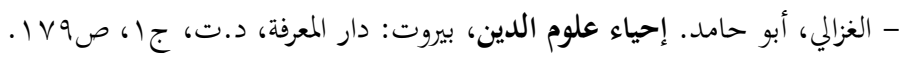

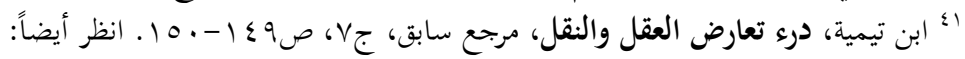

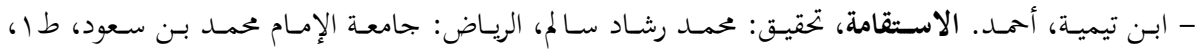

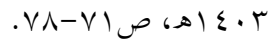

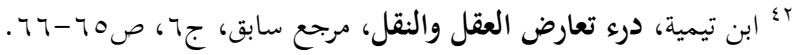

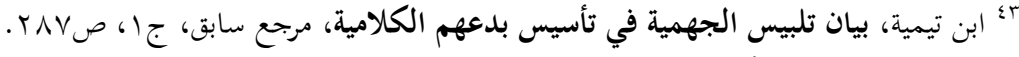

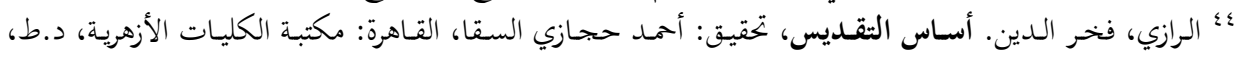


- وجود مغالطات شرعية أو مخاطرات عقلية في الأقوال أو الأفكار المخالفة. وهنا

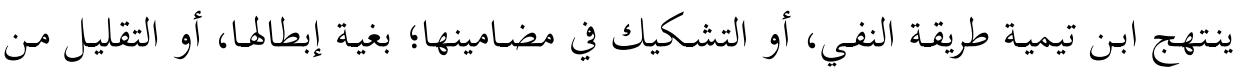

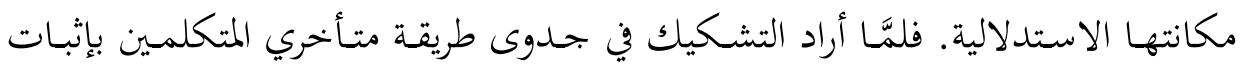

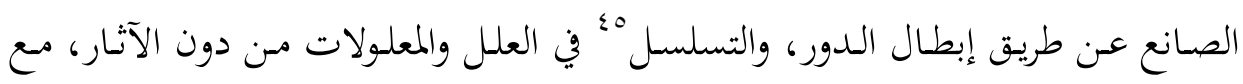

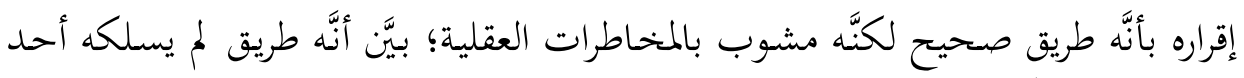

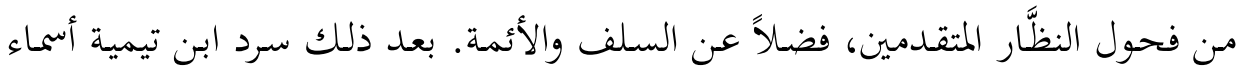

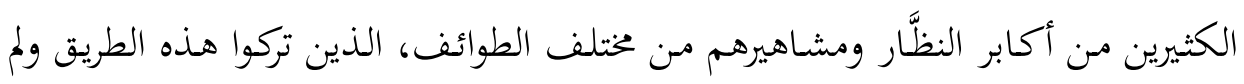

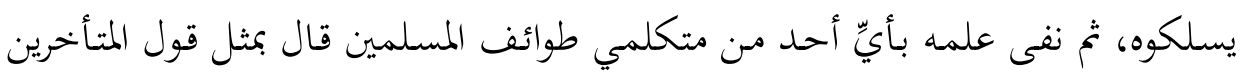

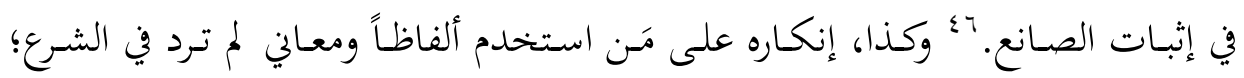

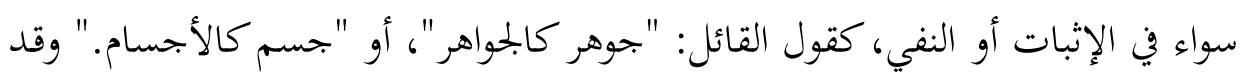

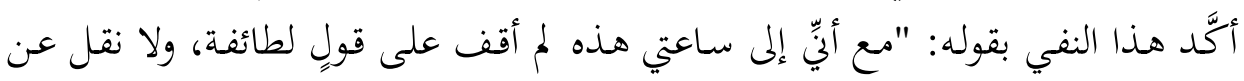
طائفة.

\section{ث. التغاير بين نسخ المصدر الواحد:}

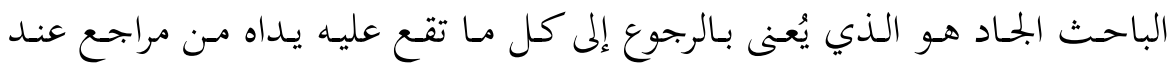

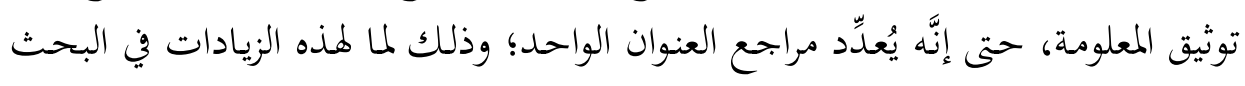

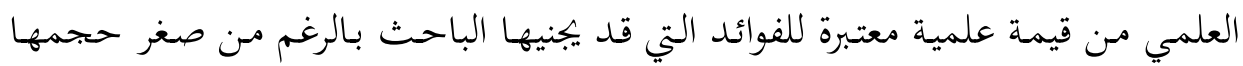

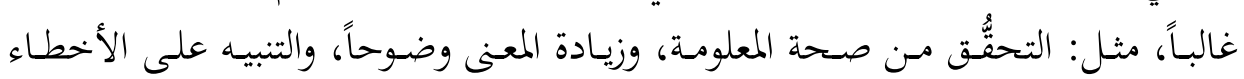
المختملة.

وهذا مـاكـان عليه ابن تيمية في تصنيفه؛ فقـد حرص على توثيق أكثر مـن نسخة

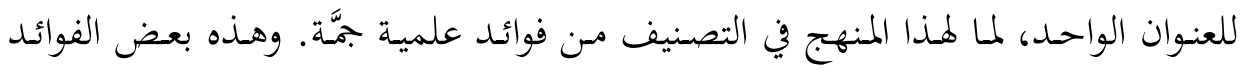

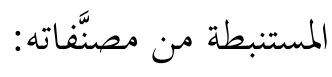

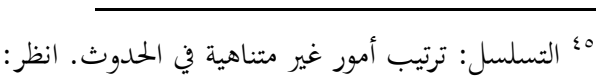

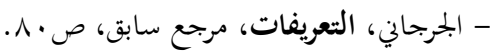

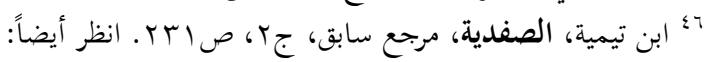

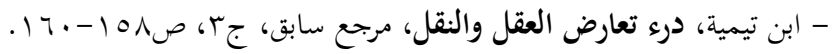

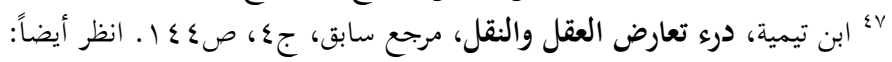

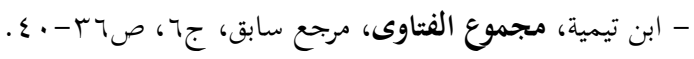




\section{- البرهنة على صحة نسبة الزيادات إلى قائليها، مع توضيح المراد منها. فقد}

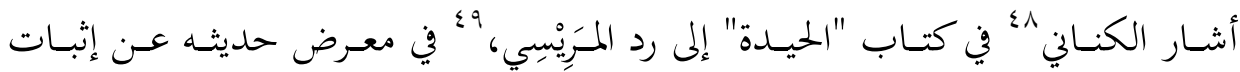

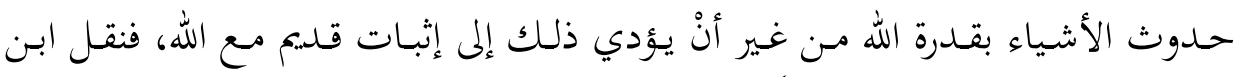

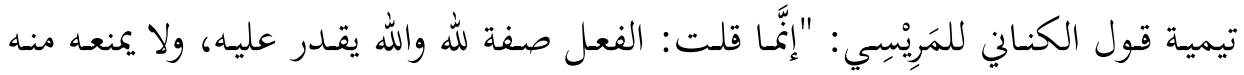

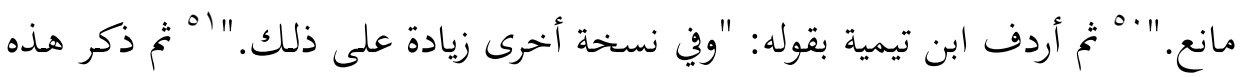

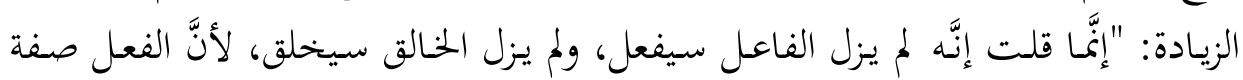

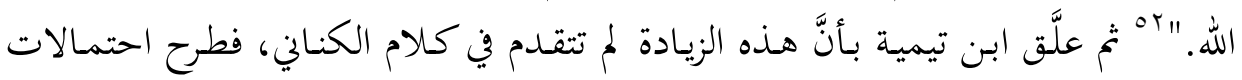

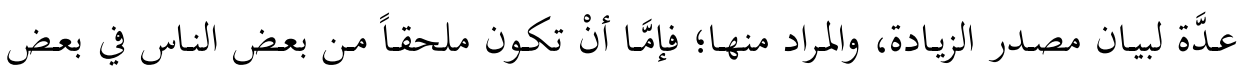

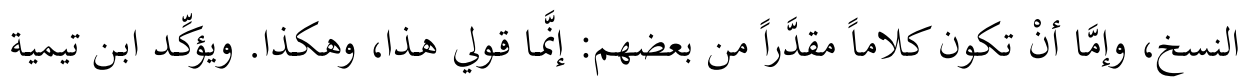

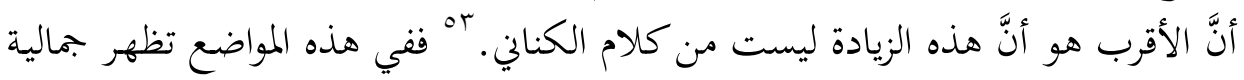

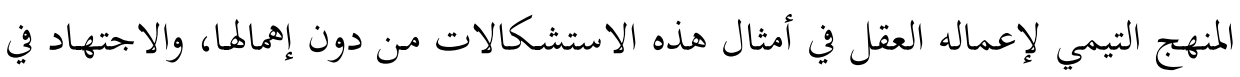
إزالة مواضع الغموض فيها.

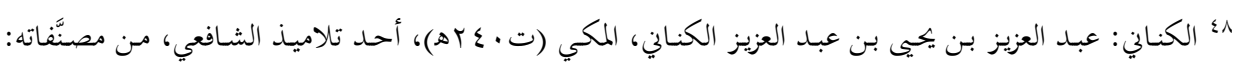

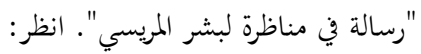

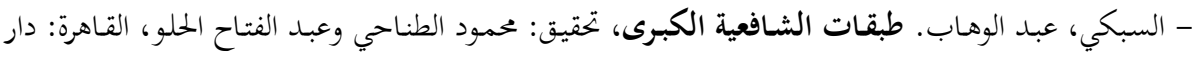

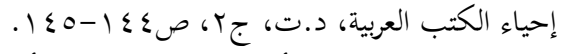

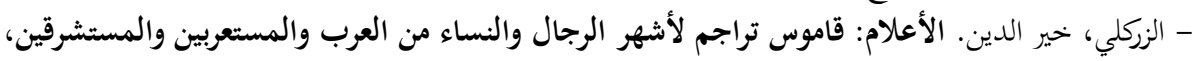

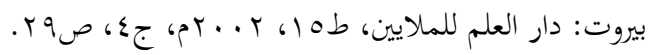

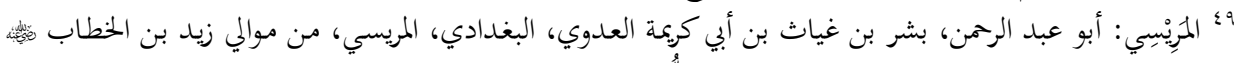

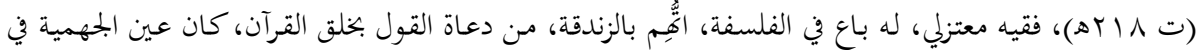
زمانه. انظر: - ابن خلكان، أحمد. وفيات الأعيان وأبناء الزمان، تحقيق: إحسان عباس، بيروت: دار صادر، د.ت، ج) .910 - الذهبي، محمد بن عثمان. سير أعلام النبلاء، تحقيق: بحموعة من المحققين، بيروت: مؤسسة الرسالة، ط؟،

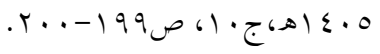

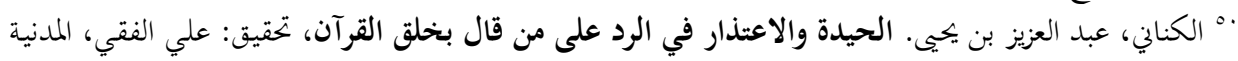

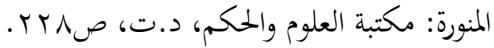

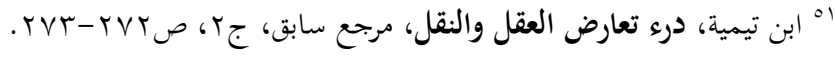

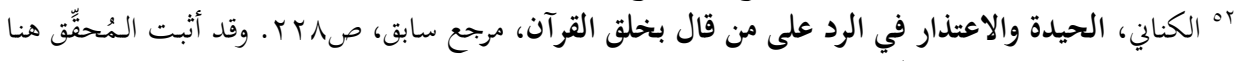

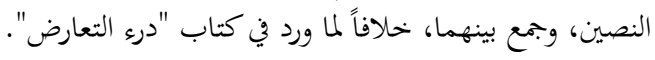

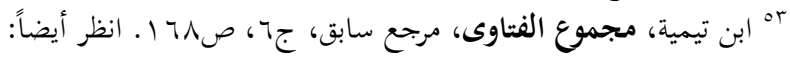

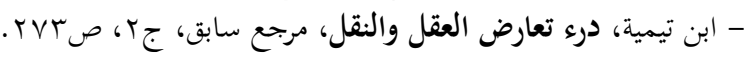




\section{- الزيادة في توضيح المعنى، وبيان المراد من النص. فحين تحدَّث ابن حنبل}

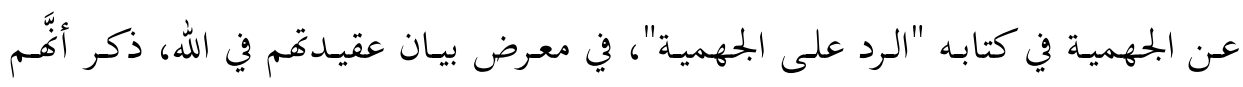

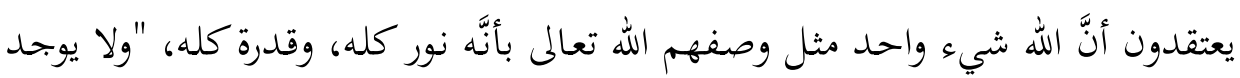

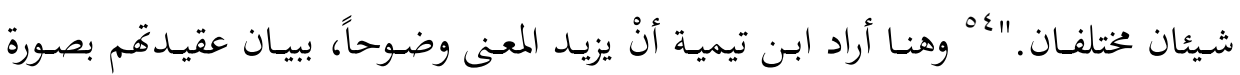

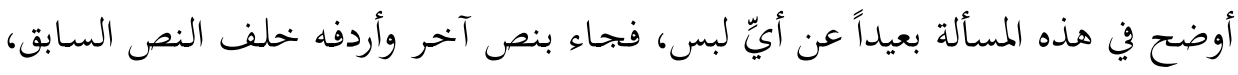

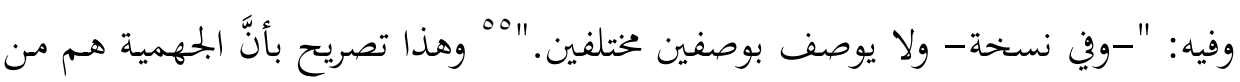

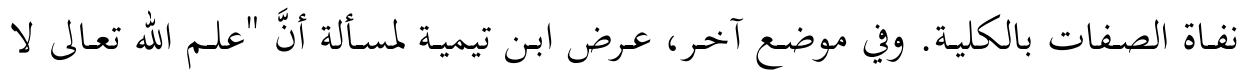

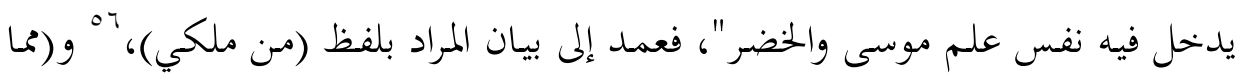

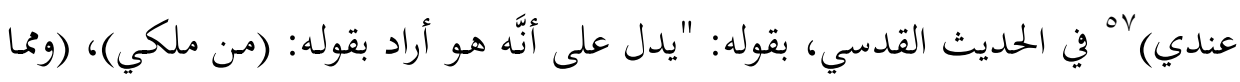

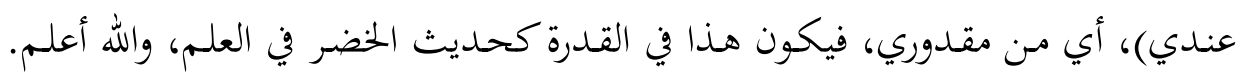

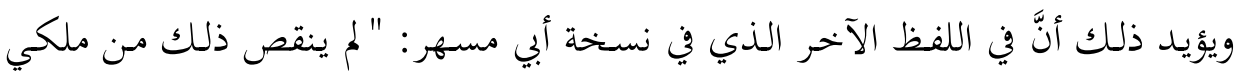

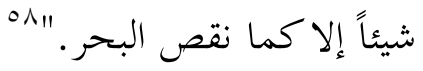

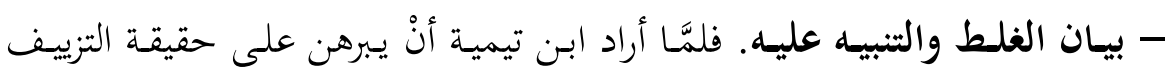

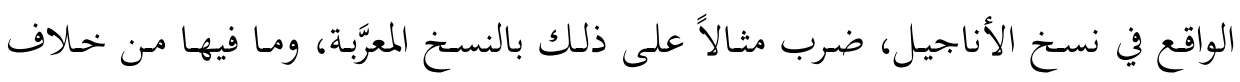

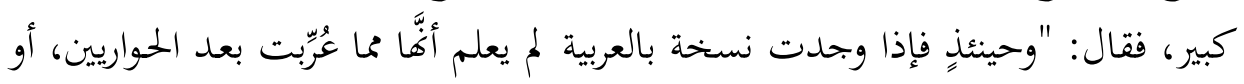

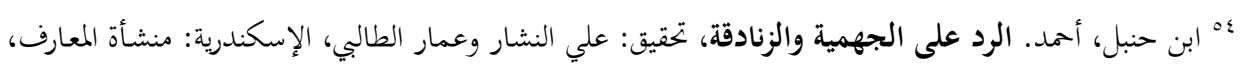

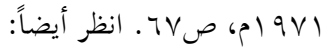

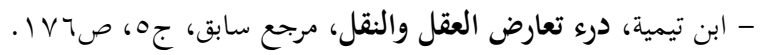

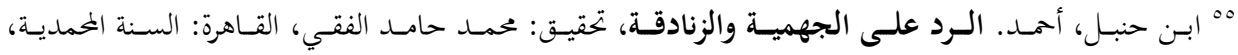

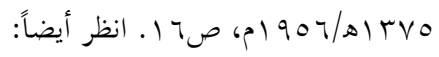

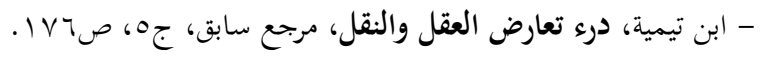

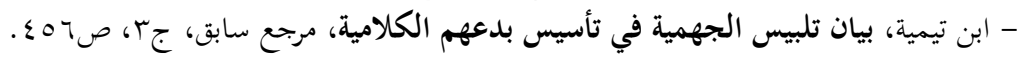

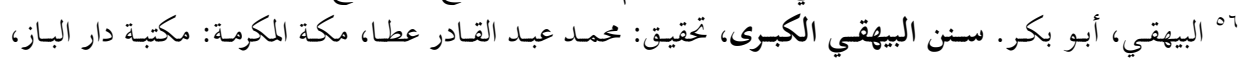

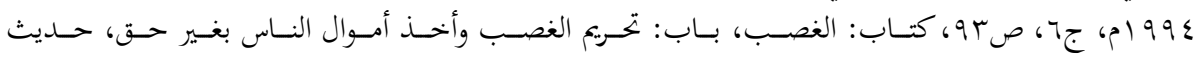

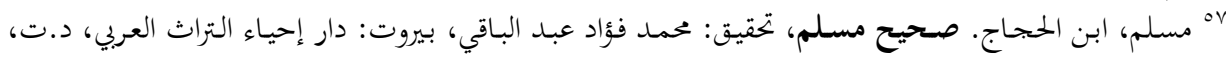

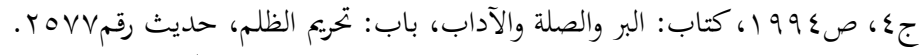

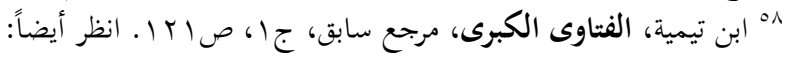

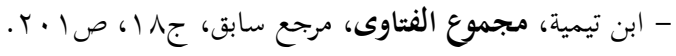


هي من المأخوذ عن الحواريين، إذا قدر أنَّه أخذ عنهم نسخة بالعربية، ولا يمكن لأحد أنْ

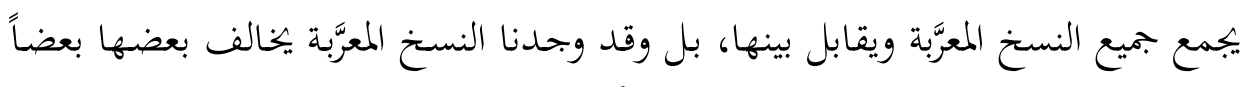

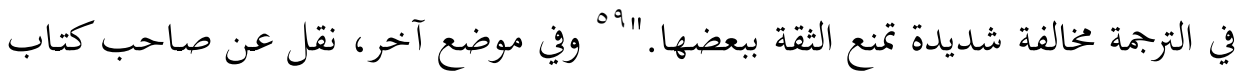

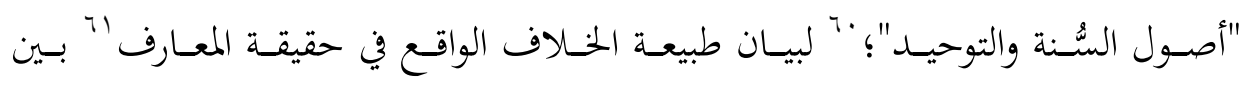

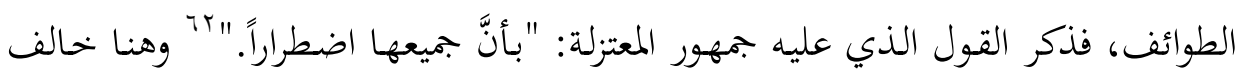

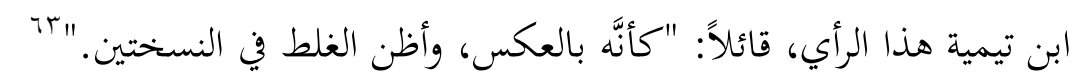

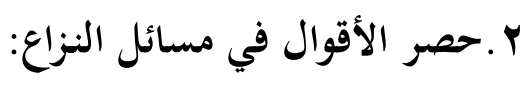

سلك ابن تيمية في مناقشاته مسـلك تحرير محل النزاع في المسائل الحلافية، وذلك

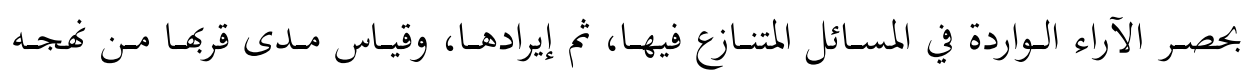
الفكري أو بُعْدها عنه.

وهنـا يُلِحُّ تسـاؤل على ذهـن القـارئ مفـاده: مـا القيمـة المعرفيـة المتوخَّاة مـن حصر

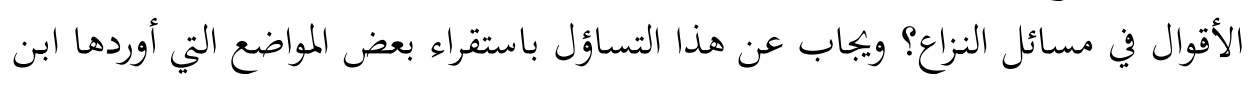

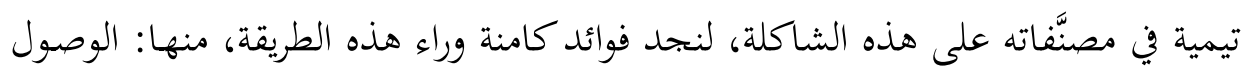

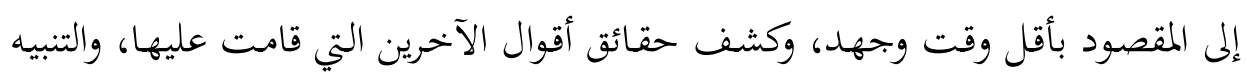

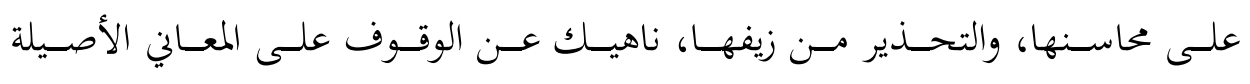

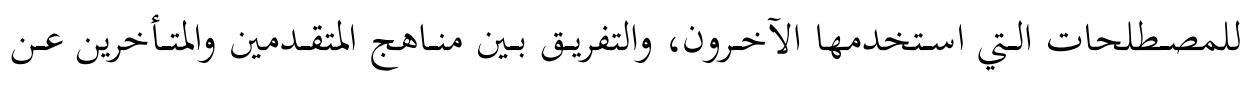

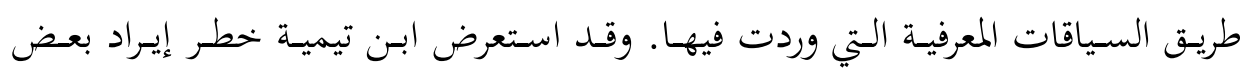

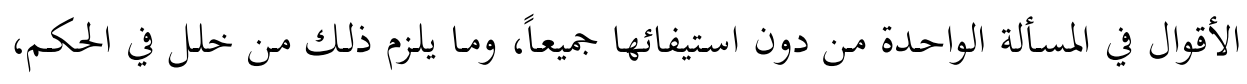

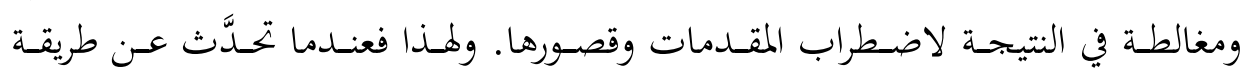
تصنيف المتكلمين في (أصول الدين)، بيَّن أنَّ القوم يوردون في مصنَّفاقمم من الأقوال ما في 9॰ ابن تيمية، أحمد. الجواب الصحيح لمن بـدَّل دين المسيح، تحقيق: وديع فتحي، مصر: دار العقيدة، طا،

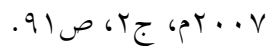

$$
\begin{aligned}
& \text { " ل لأبي محمد بن عبد البصري. }
\end{aligned}
$$

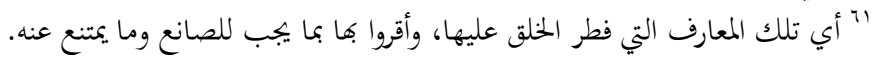

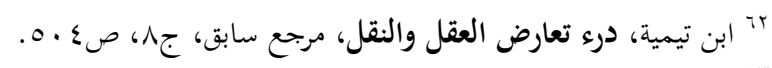

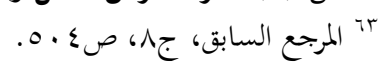


شـاء الله، فينصـرون بعضهـا، ويبطلون الآخـر، منبِّهاً على اسـتيعابهم الأقوال في المسـألة الواحدة، وإبطالها إلا قولاً واحداً لا يوردونه، مما يلزم منه تغيير معالم القضية الجحدلية التي مئي

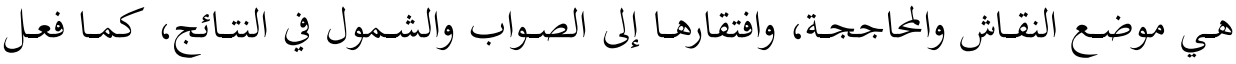

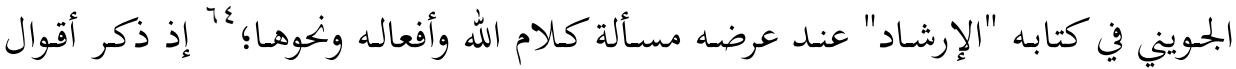

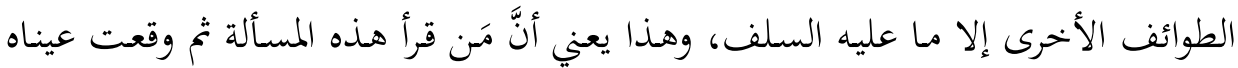
على قول السلف فيها سيتهمهم بالابتداع والافتئات على دين الله تعالى. ومن هنا قرَّر

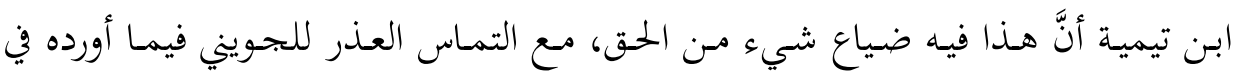
مصنَّفه.

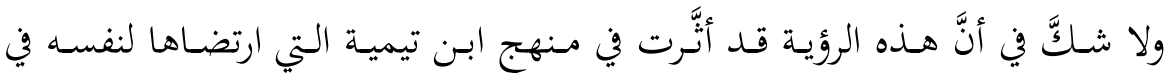
منازعاته مع مخالفيه؛ إذ إنَّه آلى على نفسه ألّا يورد قضية خحلافية من دون أن يستوفي فئي آراء

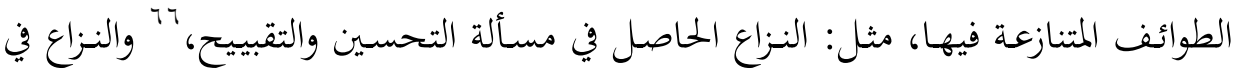

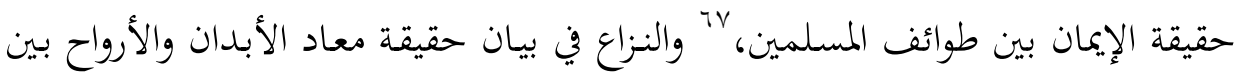
طوائف الناس.

\section{ثانياً: دعائم المنهج البحثي الموضوعي التيمي في التصنيف} يتميَّز هـذا المحسور عـن سـابقه بأنَّهـ يتصل اتصـالاً وثيقـاً بعـالم الأفكار ومضـامينها، وكيفية تبلورهـا، ويحتك بطرائق التعامـل معها مـن حيثث: النظر والاستدلال، والاجتهاد צ׳ الجويني، أبو المعالي. الإرشاد إلى قواطع الأدلة في أصول الاعتقاد، تحقيق: محمد موسى وعلي عبد الحميد،

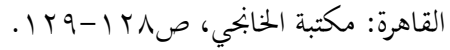

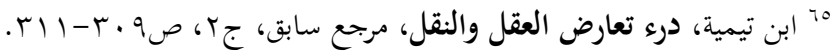

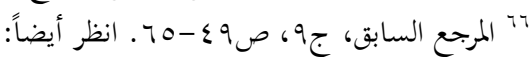

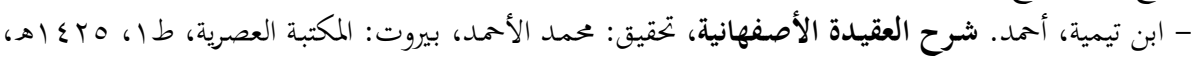

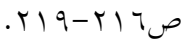

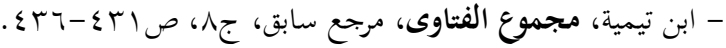

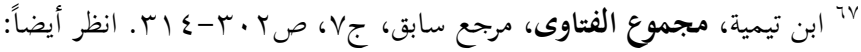

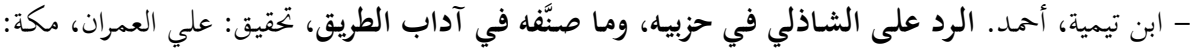

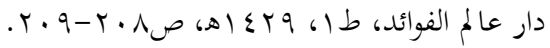

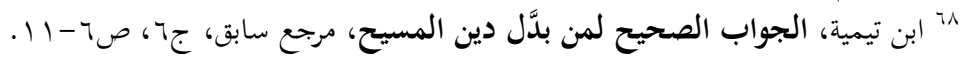


والاستنباط، وما يتصل بها من معاني الفهم والتحقيق، والتدليل والتبيين، وغير ذلك مـن دعائم البحث الموضوعي التي يرّزّ على معانيها ابن تيمية في مصنَّفاته.

\section{ا ـ النضج المنهجي في صياغة الأفكار:}

إنَّ المتأمِّل في المصـنَّفات ذات القيمـة المعرفيـة الراقيـة لـدى علمـاء المسـلمين يجــهـا

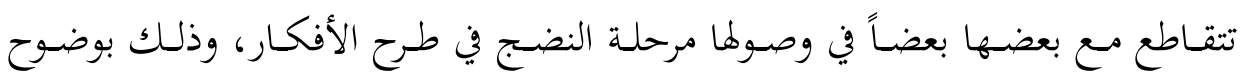
الرؤى، والتدرُّج في بسط المعارف، وترابط الأفكار. وما إنْ يبحث المرء صاحب البصيرة

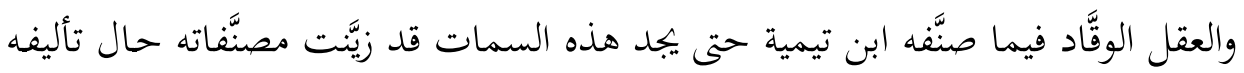

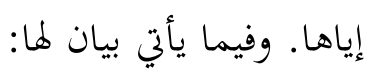

\section{أ. وضوح الؤية: - n}

تمثّل هذه السمة أحد المعالم البارزة في منهج ابن تيمية حال دفعه شبهات خصومه،

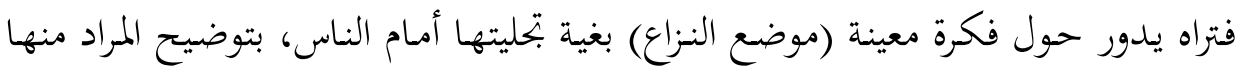
في مذهبه السلفي، والاجتهاد في بيان لوازمها الفاسدة لدى خصومهه، وهذا ما أشار إليه

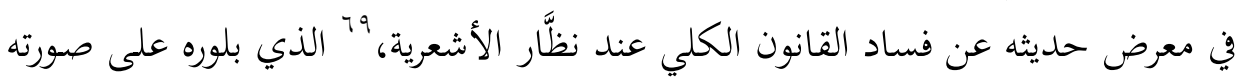
الأخيرة الفخر الرازي؛ ‘ إذ تعرَّض ابن تيمية لهذا القانون في الكثير من مؤلَّفاته، وأشهرها

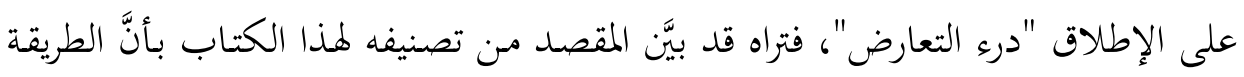

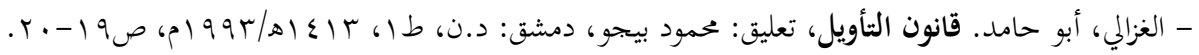

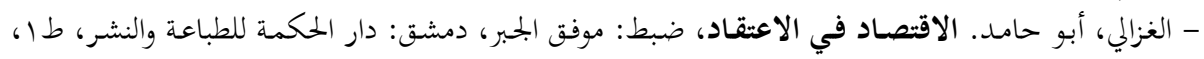

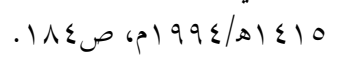

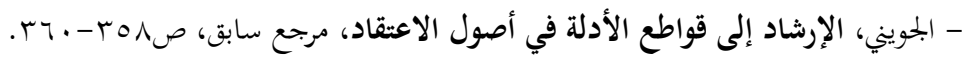

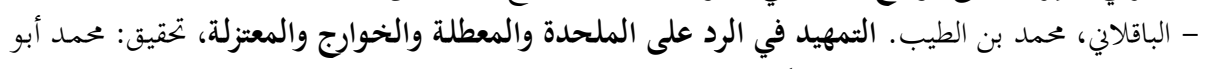

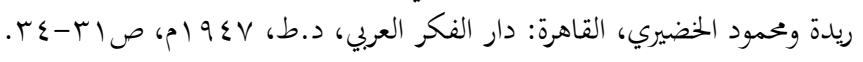

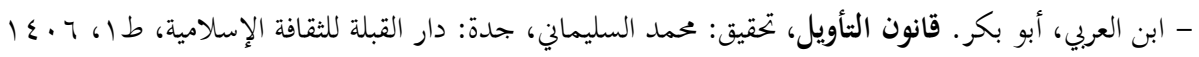
ه، ص0VO م انظر:

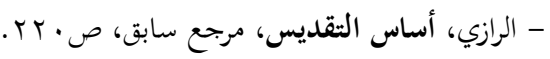

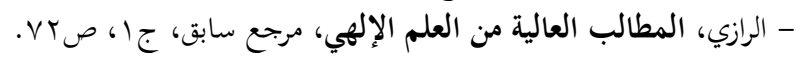




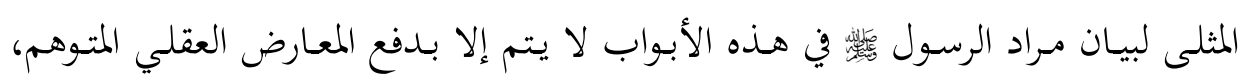

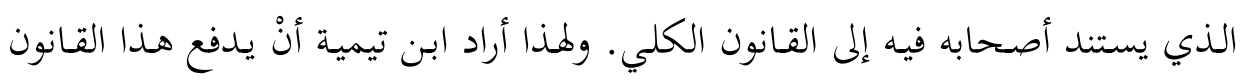

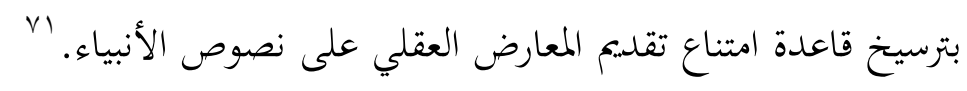

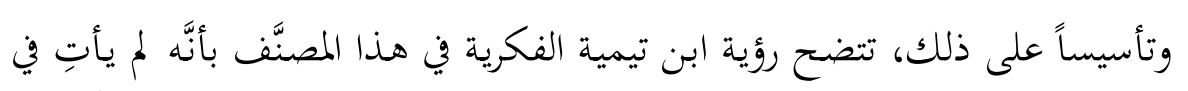

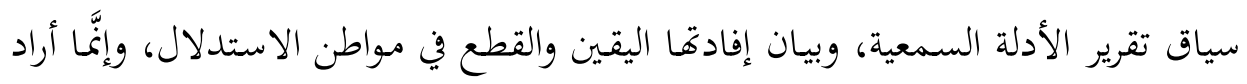

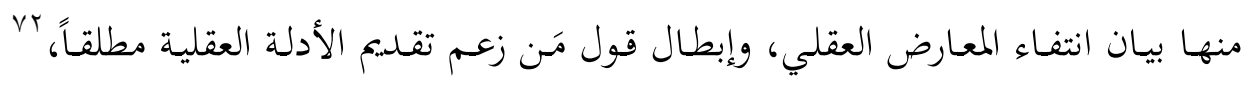

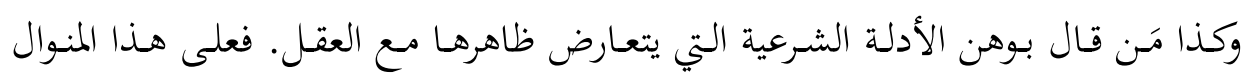
نسج ابن تيمية مؤلِّفاته.

ب. الترابط الفكري، والتدرُّج المعرفي، والبَسط البرهاني، والتوازن الجدلي:

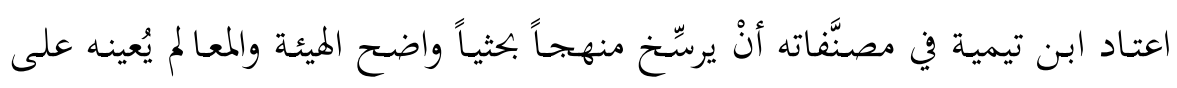

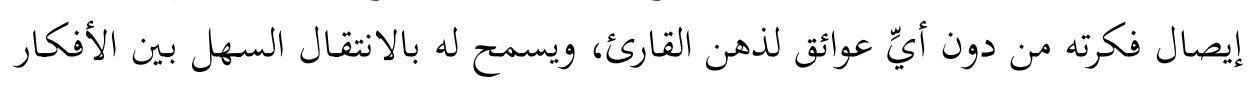

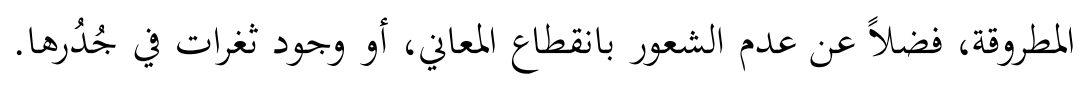

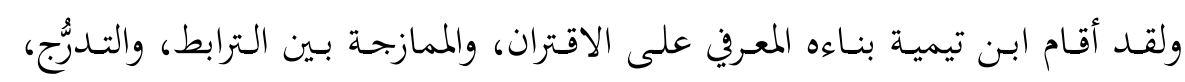

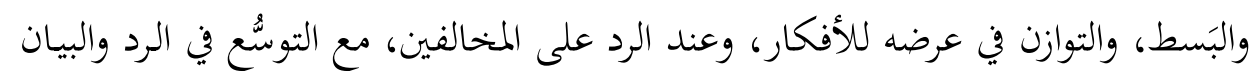
عند الحاجة.

ولبيـان ملامح منهجهـ في التصنيف، يكفينا تأمُّل ردوده على أباطيل النصارى في

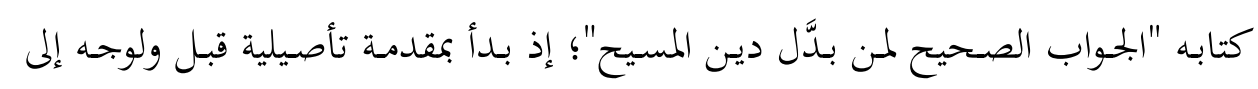

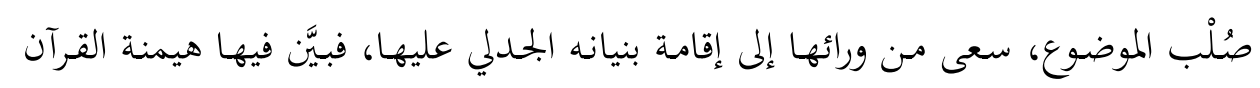

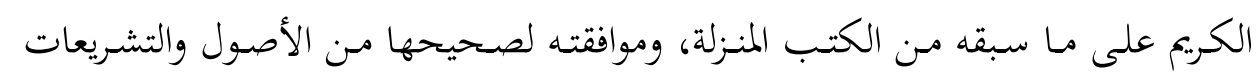

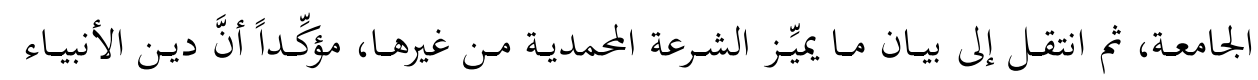

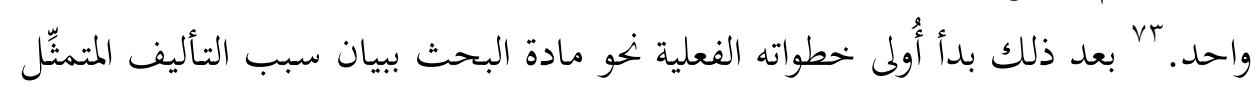

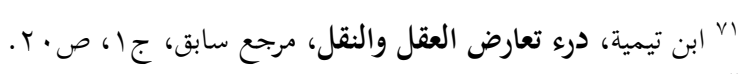

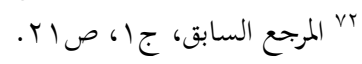

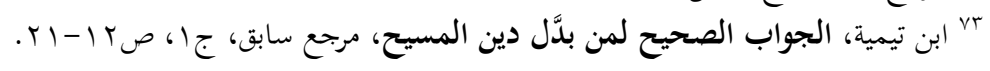


في ورود كتاب إليه من قبرص ينتصر كاتبه لدين النصارى بإيراد حجت علمائهم السمعية والعقلية الموهومة؛ قديماً، وحديثاً. گ

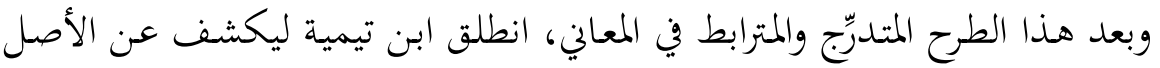

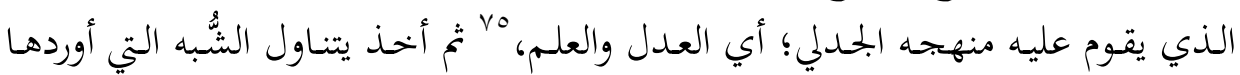

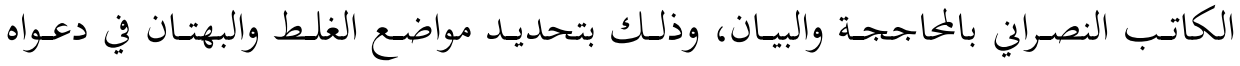

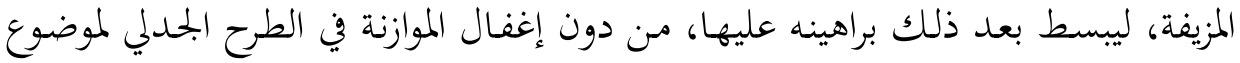

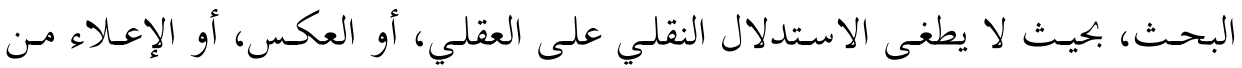

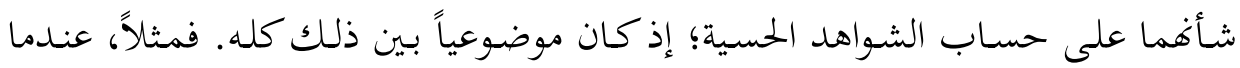

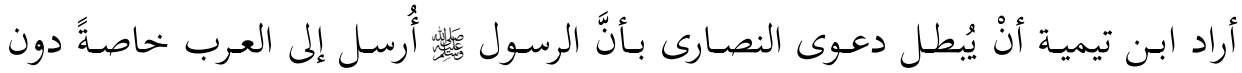

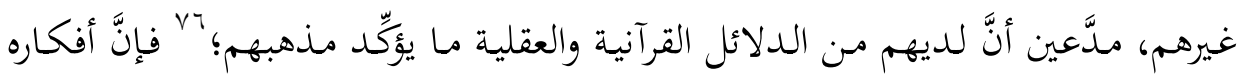

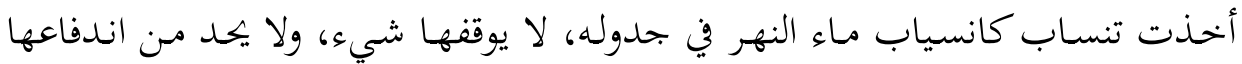

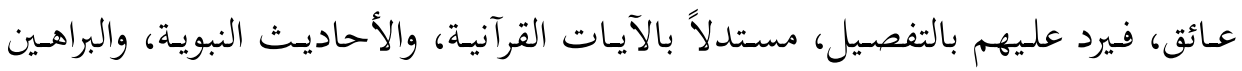

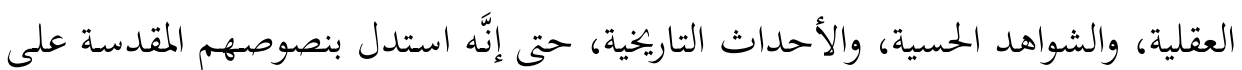

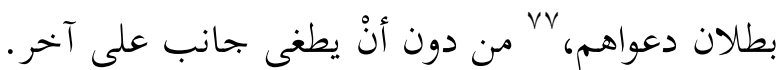

\section{r. التنوع البرهاني في الرد على المخالفين:}

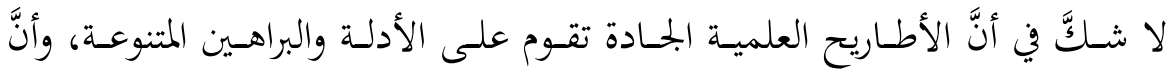

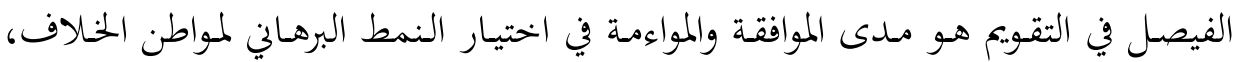

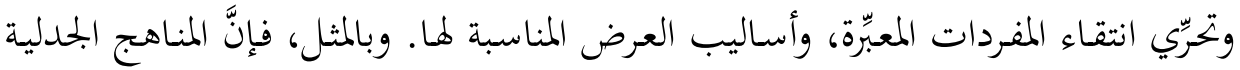

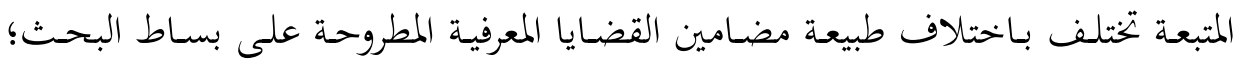

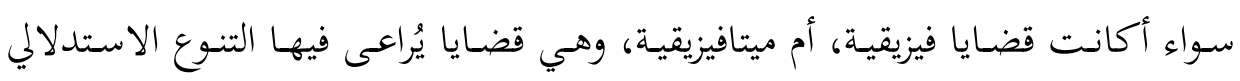

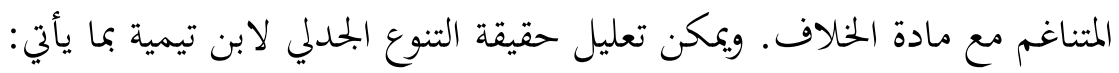

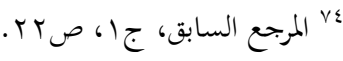

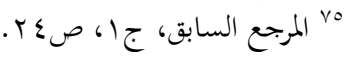

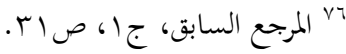

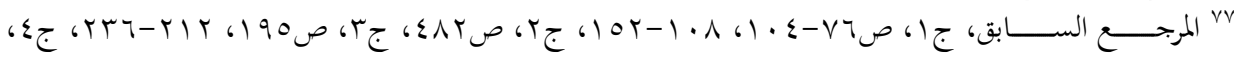




\section{أ. تعدُّد أوجه الاستدلال مع المخالف:}

تُعَدُُّ المــدافعات الفكريـة، والمنافحـات الجحدليـة بـين المتخــالفين مـن أفضـل الطرائقق لاختبـار أصالة الآراء، وصدق التوجهات، وصحة المعتقدات، ولا سيما تلك التي تقوم على ضـوابط ومعايير موضوعية. ولهـذا جـرت عـادة الصلحاء مـن أهـل العلـم أنْ يتمثَّلَوا

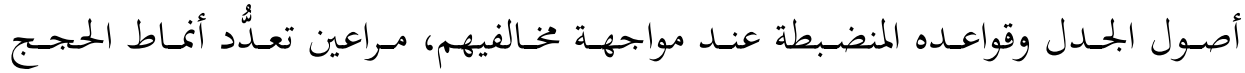
والبراهين المستخدمة في المناقشات، بحيث تشمل: الدليل النقلي، والدليل العقلي، والدليل الحسي التجريبي.

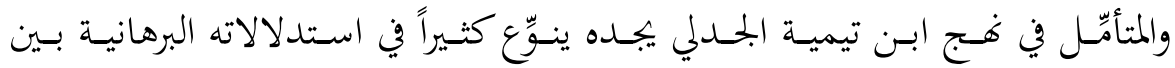

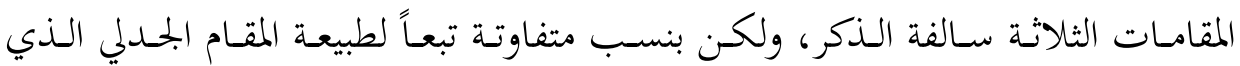

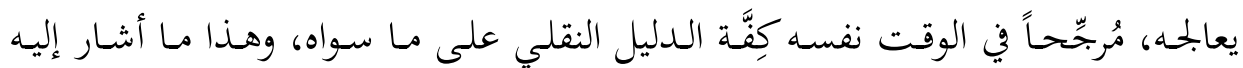
صاحب "الأعلام العلية" في بيان ماهية المنهج الاستدلالي لابن تيمية بقوله: "ليس له له

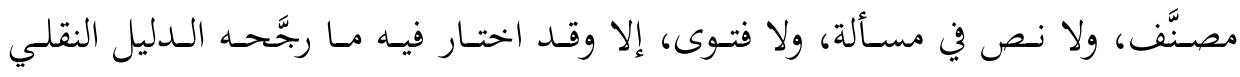

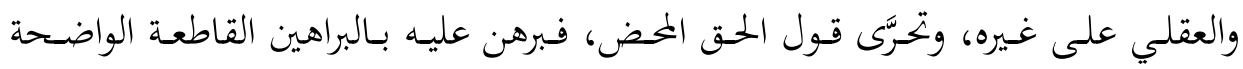

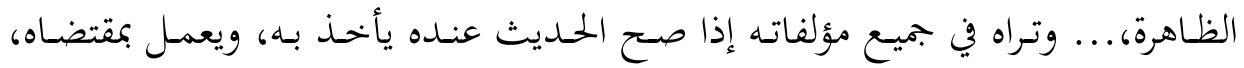
ويقدِّمه على قول كل قائل من عالم وبحتهد، وإذا نظر المنصف إليه بعين العدل يراه واقفاً

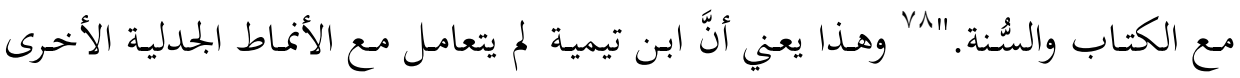
بسلبية مطلقة كما يظن بعض الدارسين.

وبالمثل، فقد تطرَّق ابن تيمية في استدلاله بالعلوم التجريبية الحسية، مثل: الطب، ول،

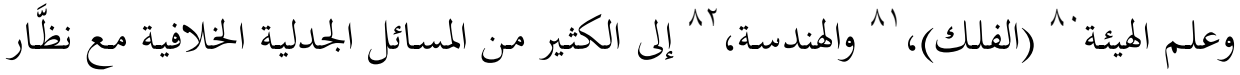
> v البزار، عمر بن علي. الأعلام العلية في مناقب ابن تيمية، تحقيق: زهير الشاويش، بيروت: المكتب الإسلامي،

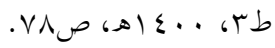
: انظ

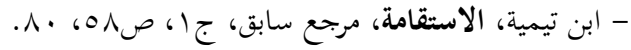

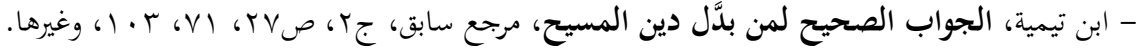

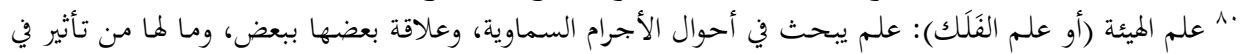




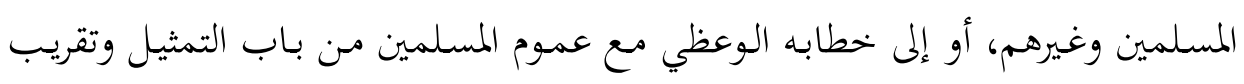
المعنى.

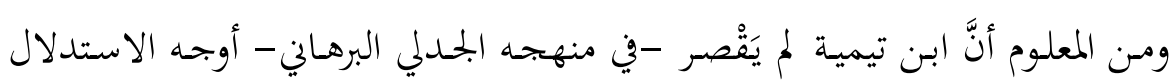

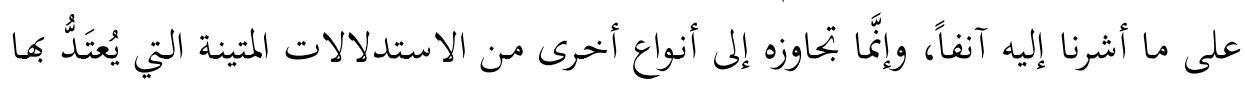

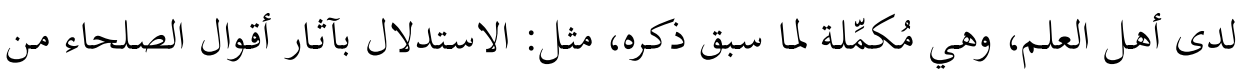

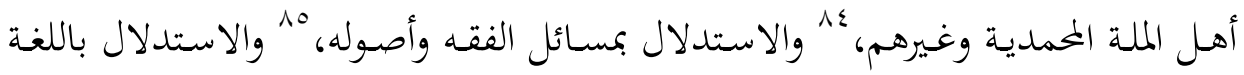

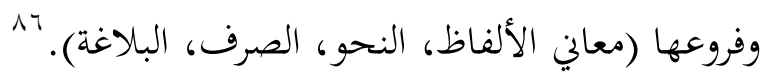

\section{ب. حقيقة موقف ابن تيمية من الدليل العقلي:}

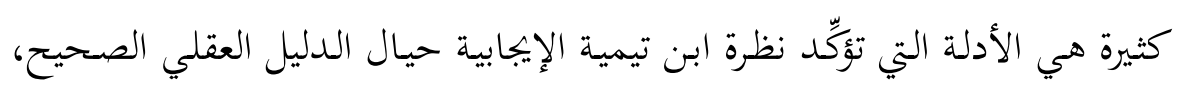

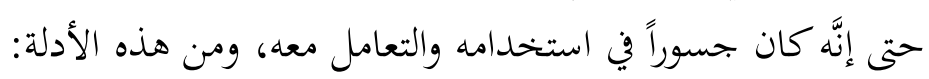

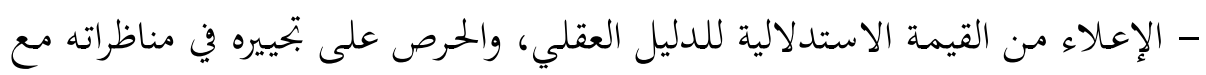

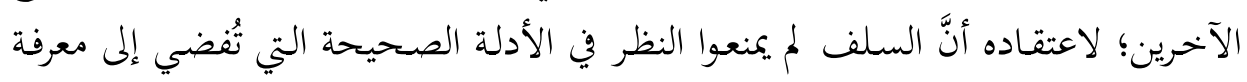

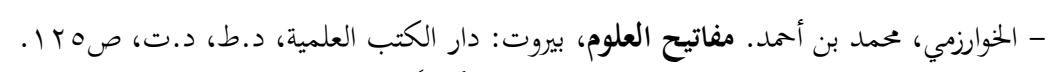

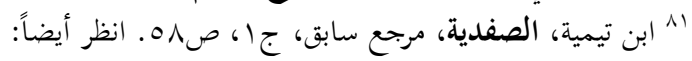

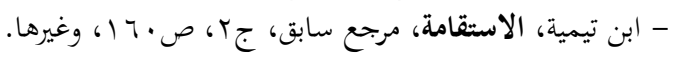

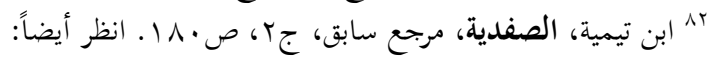

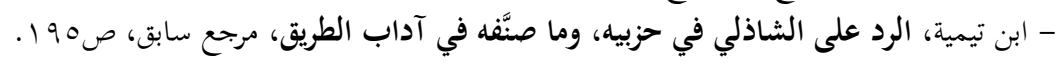

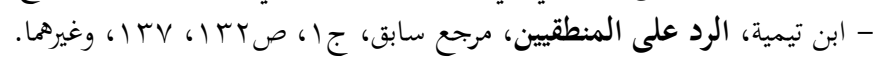

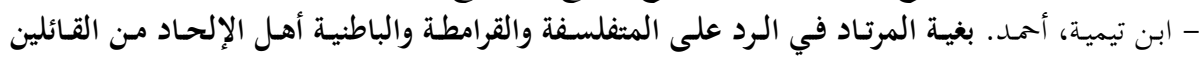

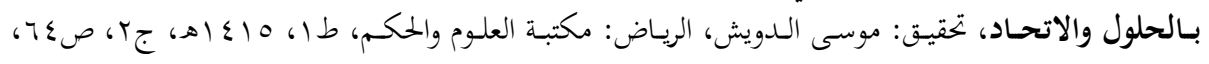

$$
\text { وغيرها. }
$$

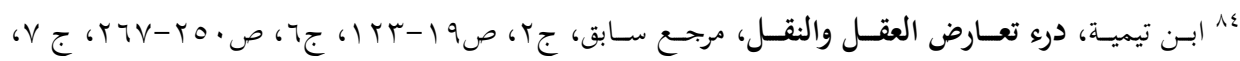

$$
\text { صن م-1، وغيرها. }
$$

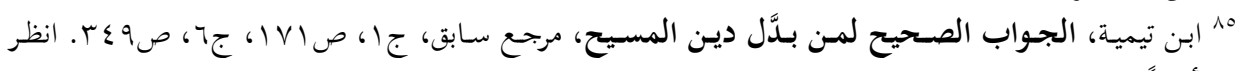

أيضاً:

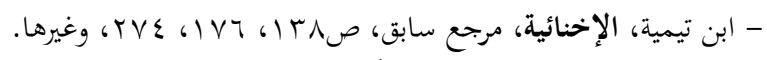

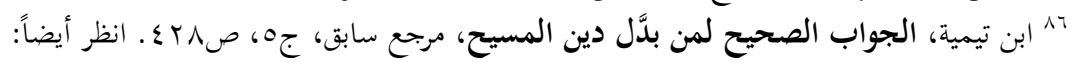

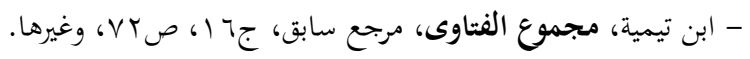


حقيقيـة غير موهومـة، ^^وأنَّ النـواتج المعرفيـة البرهانيـة الصـحيحة التي توصَّل إليهـا أهـل

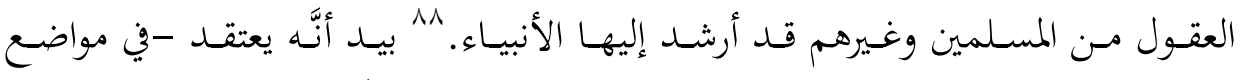

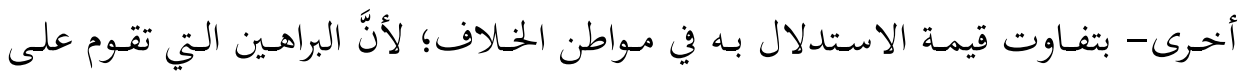

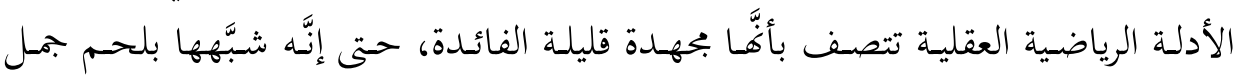

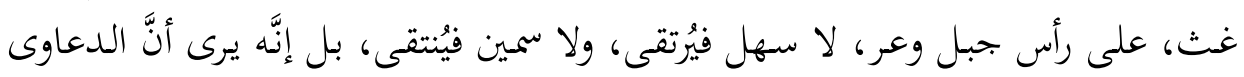

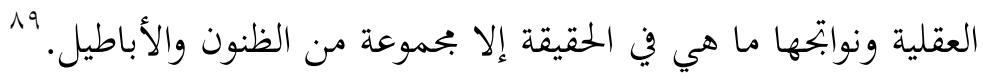
ولا شكََّ في أنَّ هذا القول يوقِع الدارس لمنهج ابن تيمية في حيرة من أمره؛ فنراه تارةً

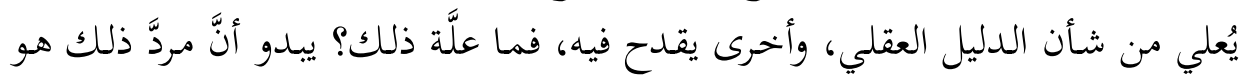

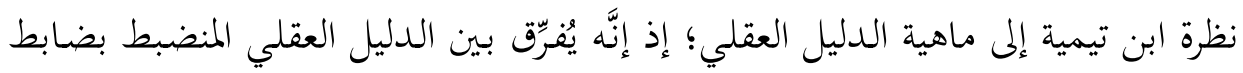

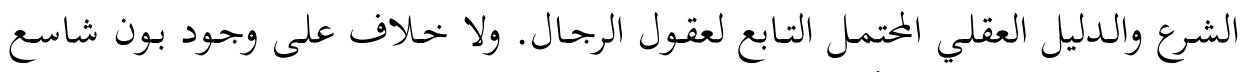

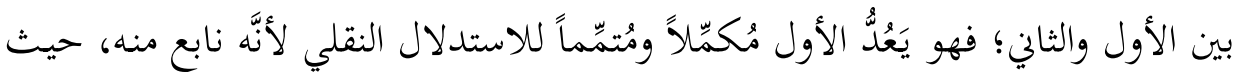

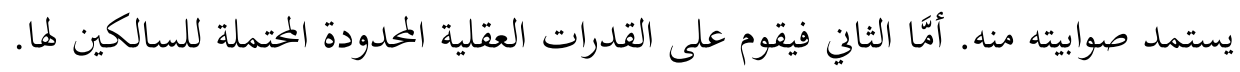
- تخطِّي الجانسب النظـري إلى الجانـب العملـي في موقفـهـ مـن الاســدلال العقلي الصحيح، وذلك باستخدامه بعض أشكاله في محاججة مخالفيه مثل المناظرة، فنجده قرَّر

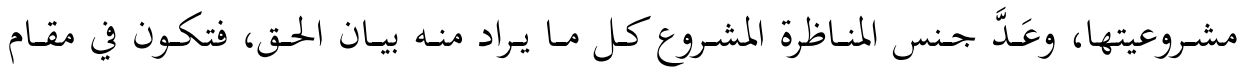

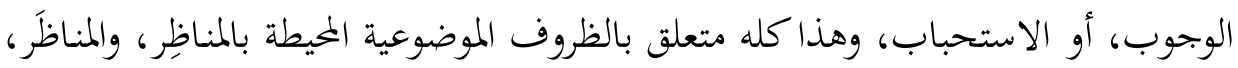

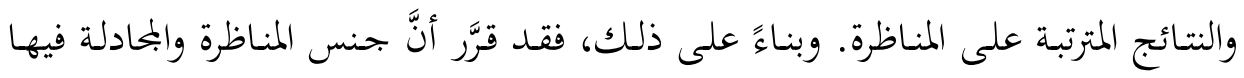

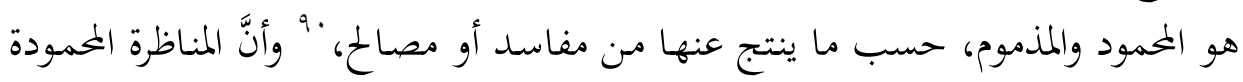

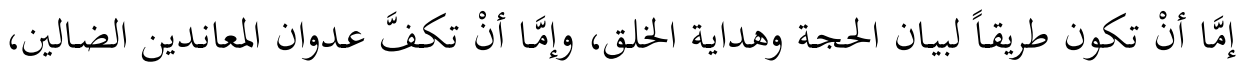

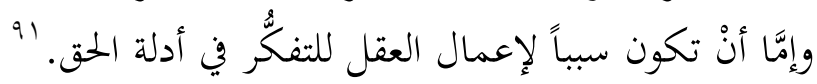

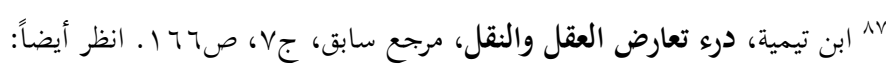

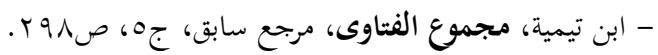

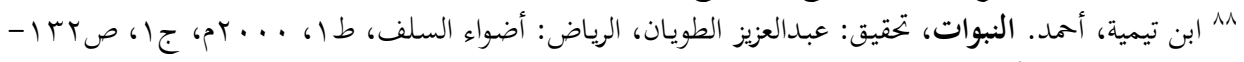
rابر ا انظر أيضاً:

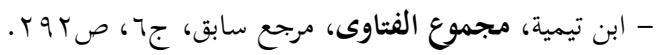

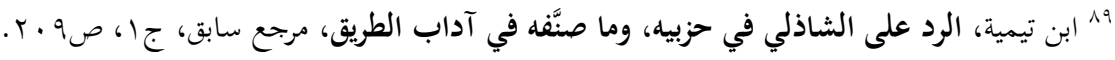

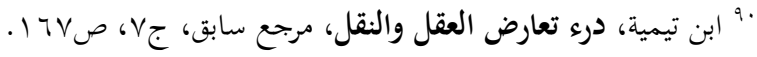

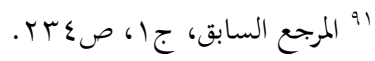




\section{ت. أنماط صياغة الدليل العقلي: - م}

يذهب ابن تيمية إلى أنَّ الدليل العقلي يُستنبَط إمَّا من أقيسة عقلية بَ ورد ذكرها في

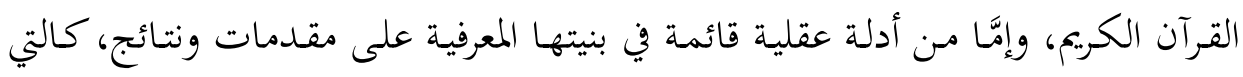

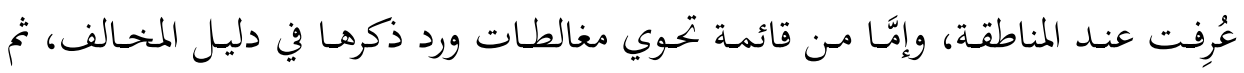

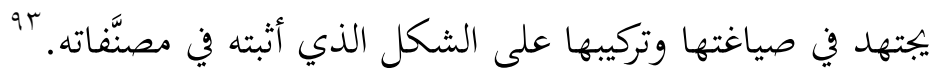

\section{ث. غرض التنويع في أوجه الاستدلال:}

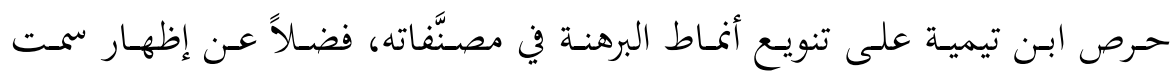
العلمية والموضوعية فيها؛ سعياً إلى تحقيق الأهداف الآتية:

- إظهار حالة الثراء المعرفي في التراث الفكري الإسـلامي، ولا سيما في ظل وجود

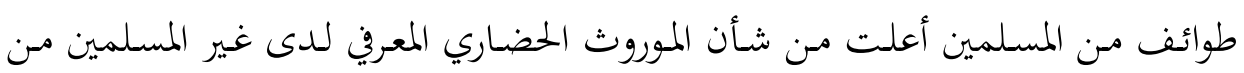
وثنيين وغيرهم. - البرهنة على صحة الفكرة، وتمتين أوجه الاستدلال، وتقوية السياق البرهاني بهذا التنويع. - اعتبار هذه المنهجية الجحدلية طريقة موثوقة في الإلزام، وأقوى في إفحام المخالفين، فضلاً عن تعزيز فكرته.

rو الأقيسة العقلية: استنباط البمهول من المعقول، واستخراجه منه، ويراد به في القرآن الأمثال المضروبة، ومن أنواعه:

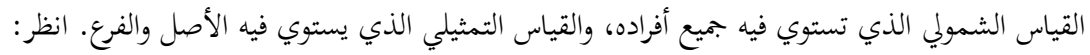

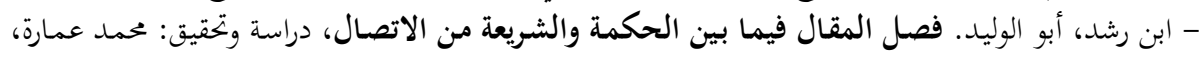

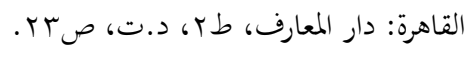

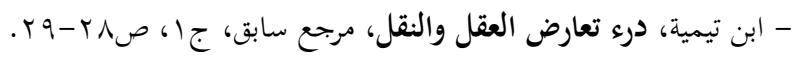

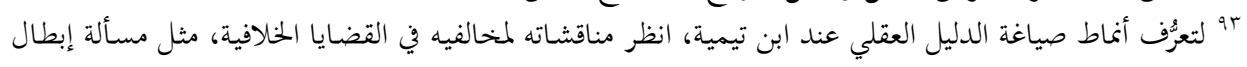
القول بعدم غهاية الحوادث في:

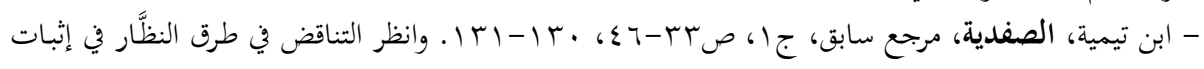
واجب الوجود في:

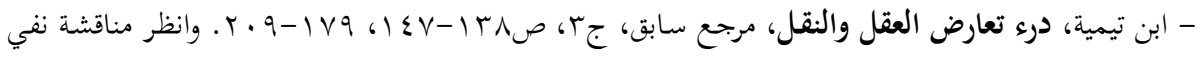
التركيب في:

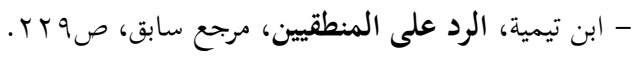




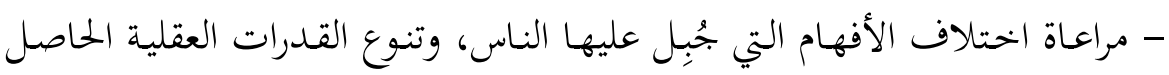

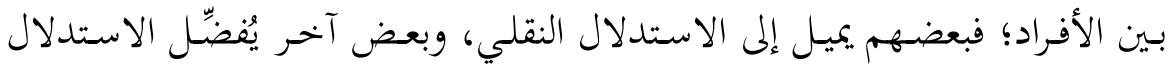

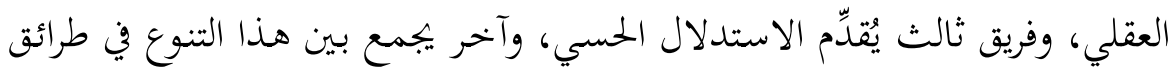

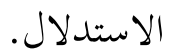

ولا شكَُّ في أنَّ هذا التعاطي من ابن تيمية - في كثير من الموضوعات- مع القضايا

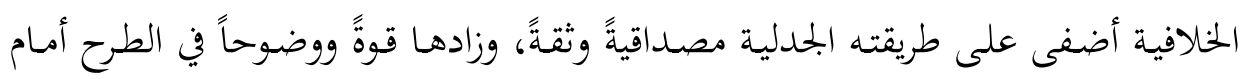
الآخرين من الموافقين والمخالفين.

\section{r. التفريع المنطقي للمسائل الخلافية:}

اعتمد ابن تيمية طريقة التقسيم والتفريع لمسائل الخـلاف التي خاضها مع الآخر، وربط بينها وبين متعلقاتا اللازمة التي برزت بصورة واضحة فينة الفين مصنَّفاته.

\section{أ. الإجمال ثم التفصيل في تقسيم مسائل الخلاف:}

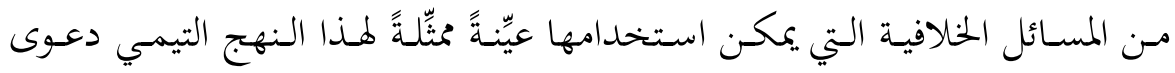

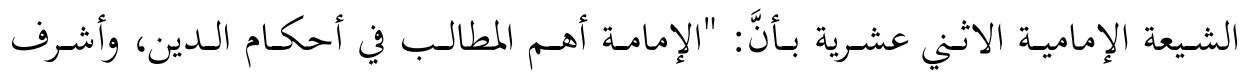

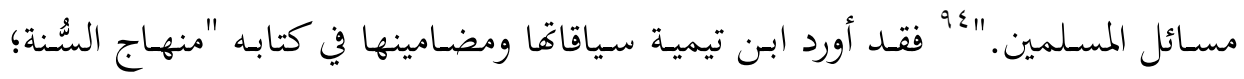

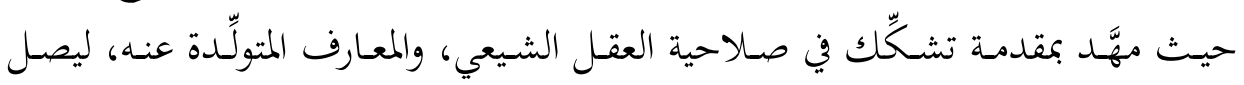

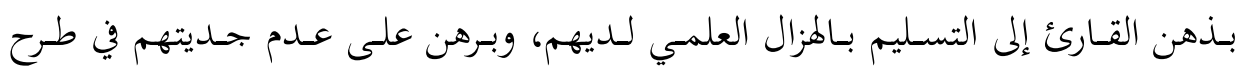

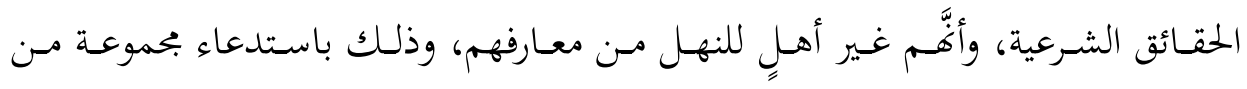

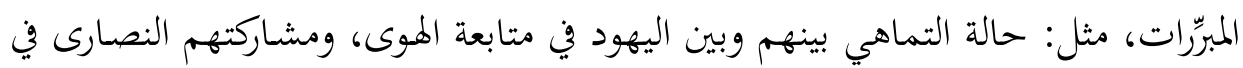

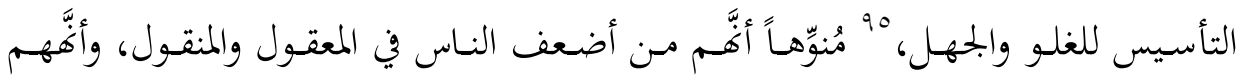

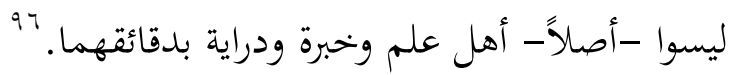

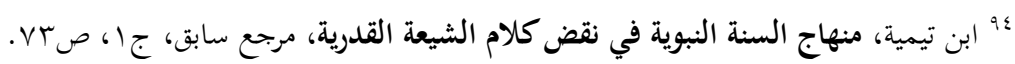

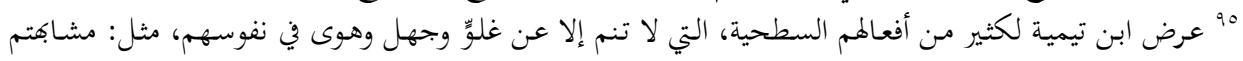

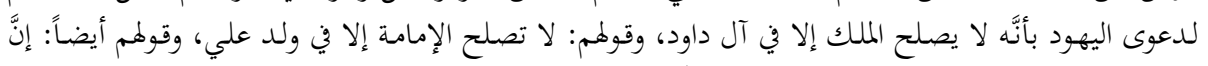

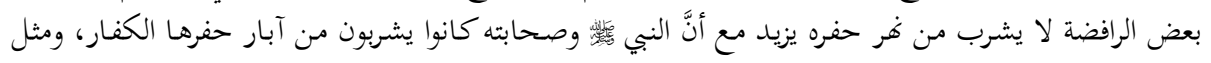




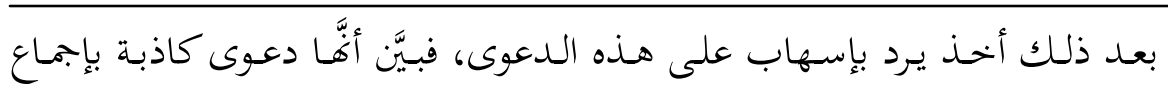

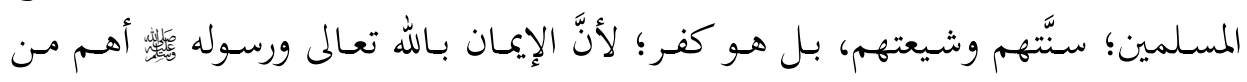

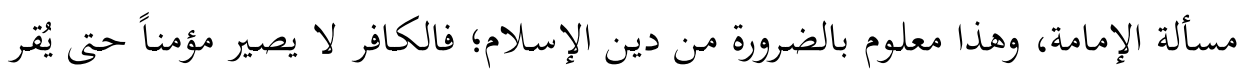

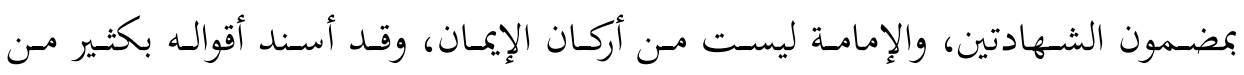

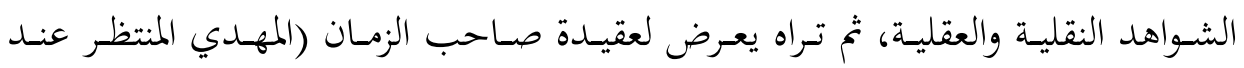

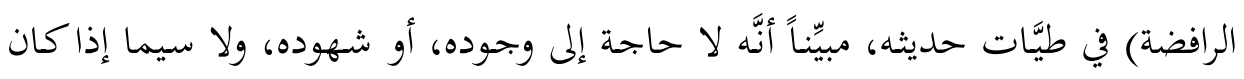

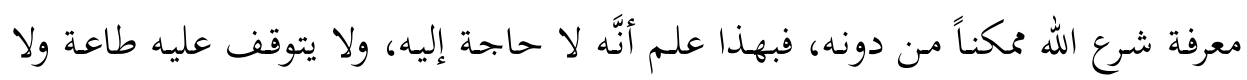

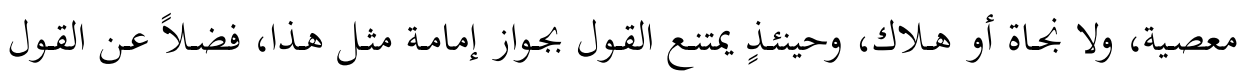

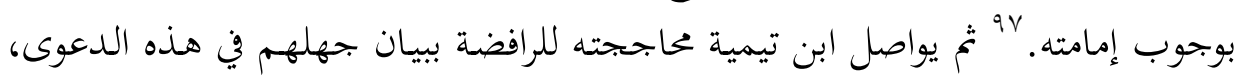

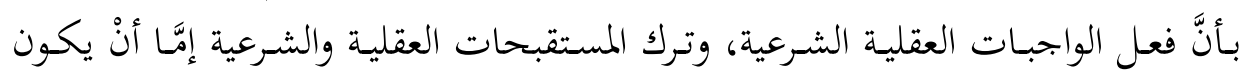

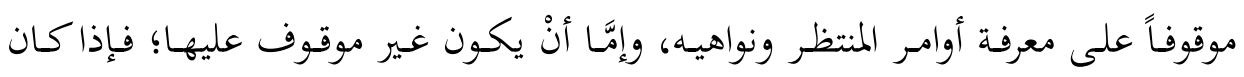

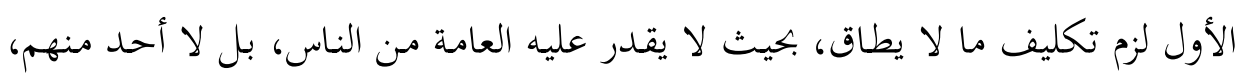

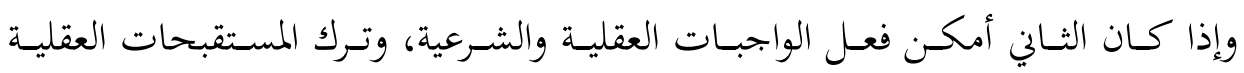
والشرعية من دونه، فلا يحتاج إليه، ولا يجب وإنب وجوده، ولا شهوده. بعد ذلك عرض لدعوى فرعية أخرى مفادهـا أنَّ الرافضـة يجعلون إيمافم بـالمنتظر

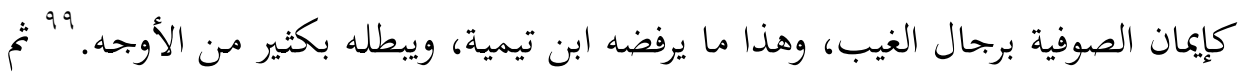

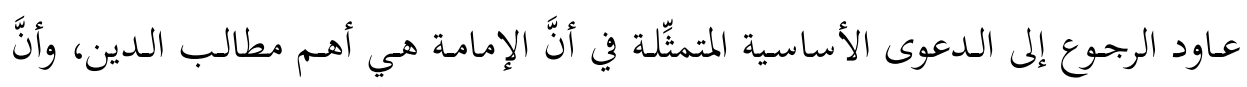

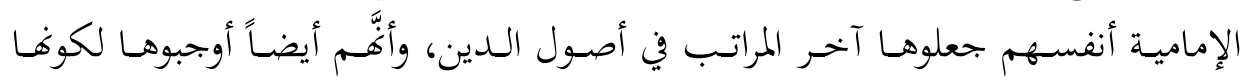

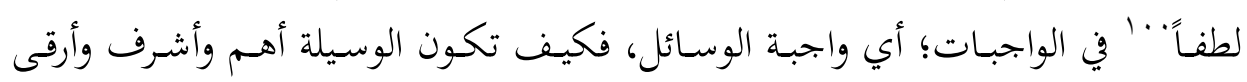

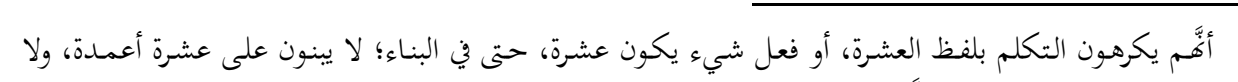

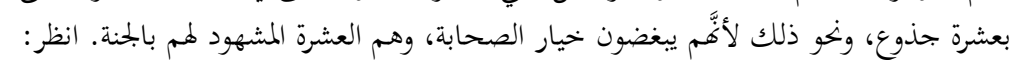

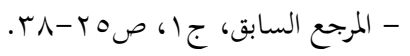

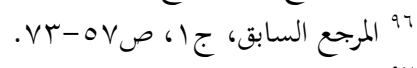

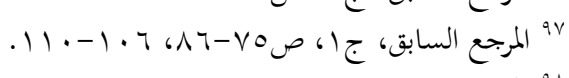

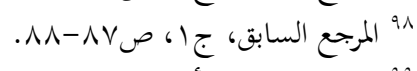

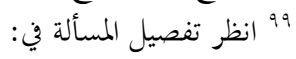

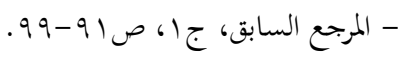

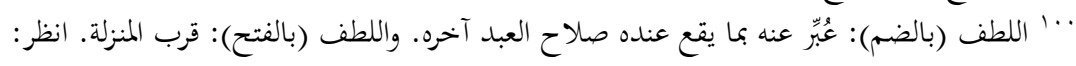




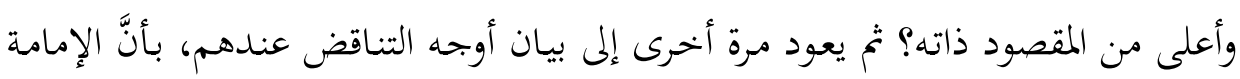

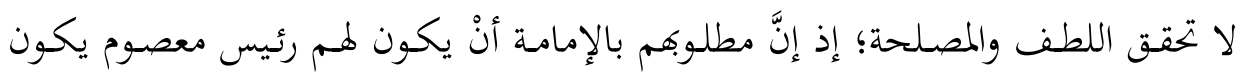

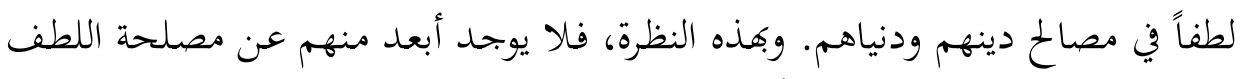

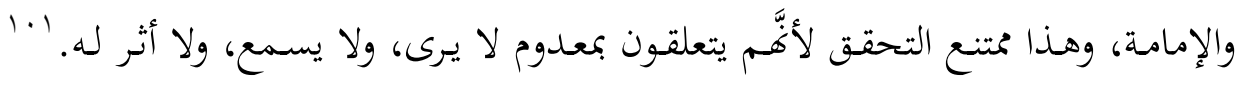

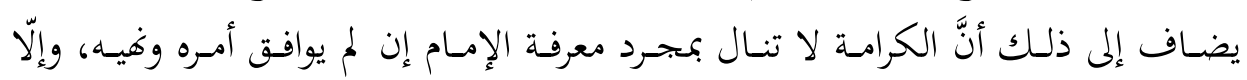

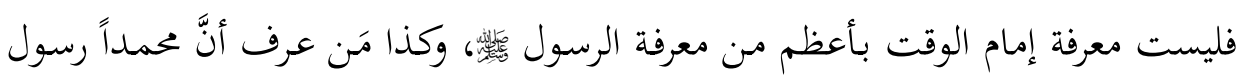

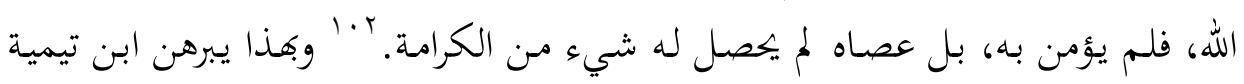

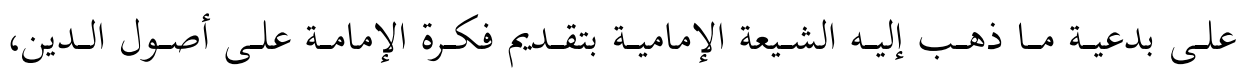

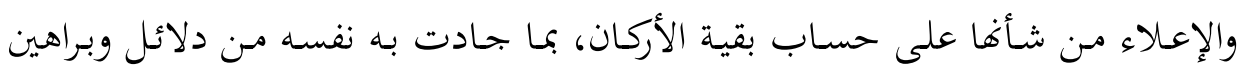
بثَّها في مواضعها.

\section{ب. فوائد تفريع الأفكار عند التصنيف:}

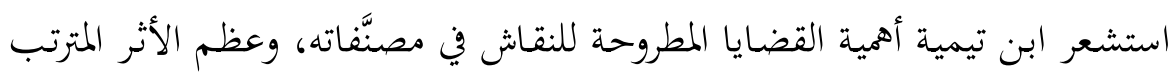

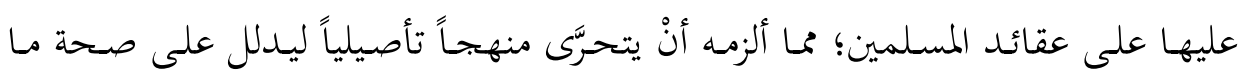

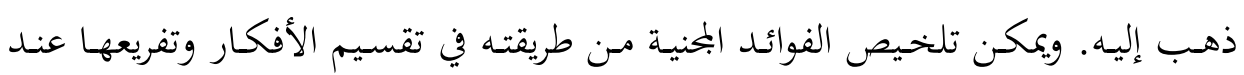
التصنيف فيما يأتي:

- التركيز على الصياغات العلمية الصحيحة في الكتابة والتوثيق عند البرهنة على البـ صحة توجُههه، التي يمكن اختزالها في النمط الآتي: الاهتمام بتنويع الأدلة عند إيرادها، ما بين أدلة نقلية، وما يتبعها من آثار وأقوال

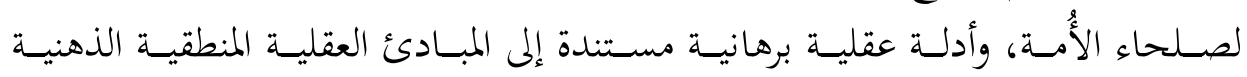

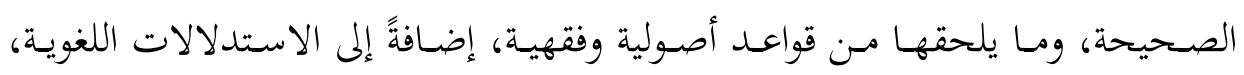

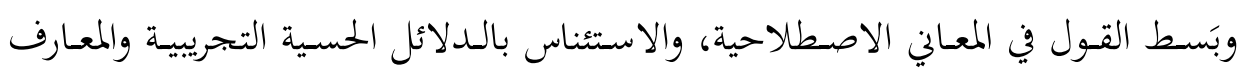
المتنوعة المتعلقة بمباحث النقاش في المعاي الاصط.

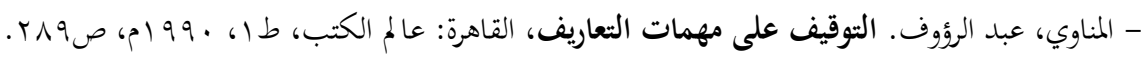

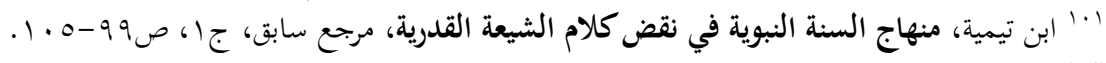

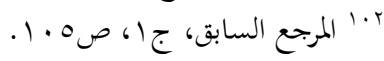


التوثيق العلمي الصحيح والدقيق للمعلومات من مظاها ومصادرها إن أمكن، أو

$$
\text { الإشارة إلى مصدر النقل عند فقدان الأصل. }
$$

- إبراز الآثار السلبية في دقائق أفكار المخحالف بعد التفكيك والتفريع، مثل: بيان المخالفات العقدية والتناقضات الفكرية عند القائلين بها، وتسلُّط المنحرفين عليهم. - خلـوص تفريـع الأفكـار إلى تبسـيط مضـامينها، ثم بيـان مـــى موافقتهـا لطرائـق

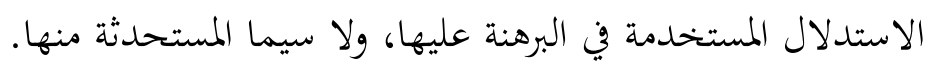
- توضيح حقيقة أحوال المعتقدين الفكرية، وبيـان موافقاقم ومخالفـاهم للمعتقدات الصحيحة.

- تفصيل القول في أصل الفكرة، الذي يُجتِّم بيان مدى أصالتها في تاريخ الأفكار،

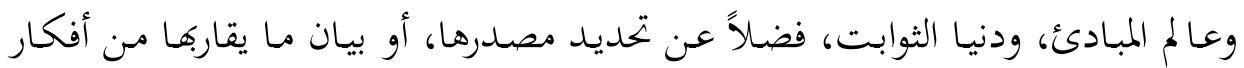
عند الملل والنّحل الأخرى؛ ما يُيسّر عملية إفحام الخضصم، وإلزامه بالحق. - زيادة تفصيل الأفكار وتقسيمها يفتح مزيداً مـن أبواب الفكر المغلقة؛ مـا يثري

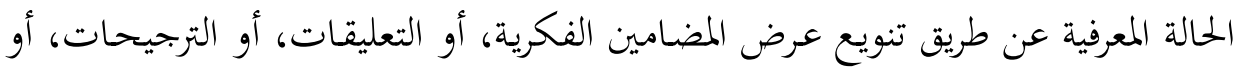
الاختيـارات المتعلقـة بجـوهر الفكرة، بقصـد تـدعيم النتائج التي توصَّل إليهـا، والتي يريـد إيصالها إلى أصحاب الشأن.

\section{ت. القيمة المعرفية لاستطرادات ابن تيمية المطوَّلة:}

لا بُسََّّ مـن الإشـارة إلى الأسـلوب الـذي انتهجـهـ ابـن تيميـة في كثـير مـن مصسنَّفاته،

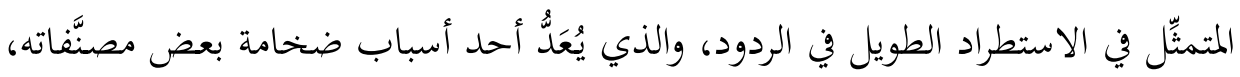

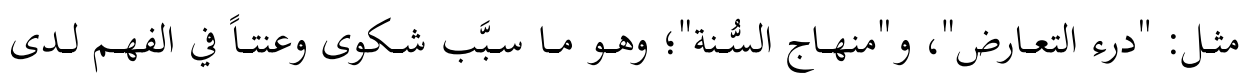

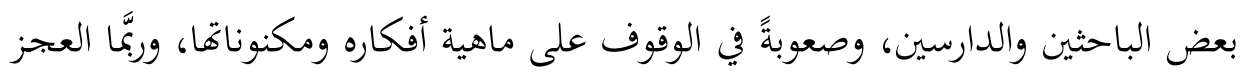

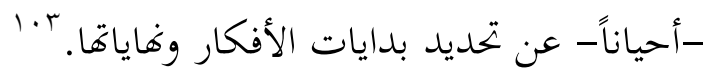

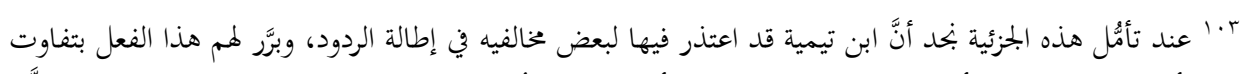

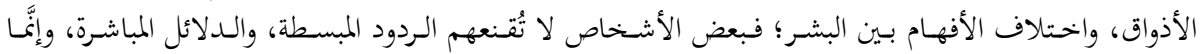




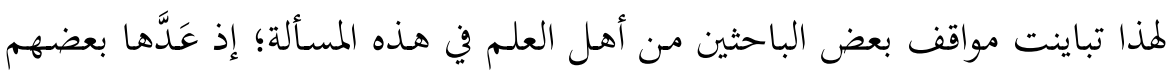

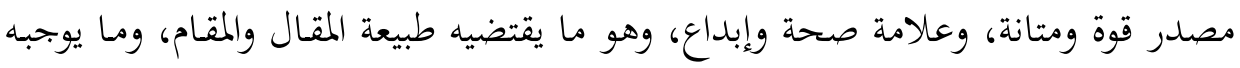

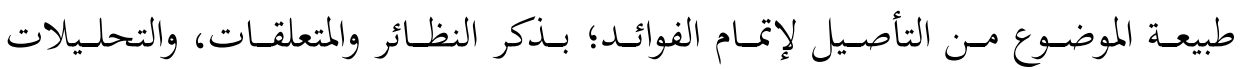

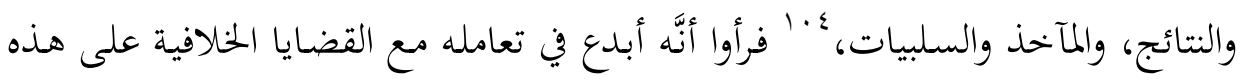

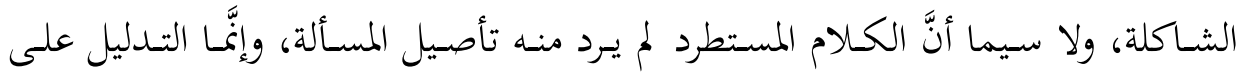

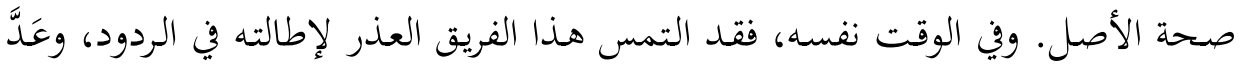

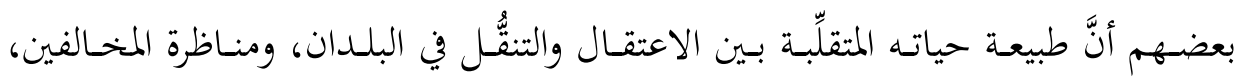

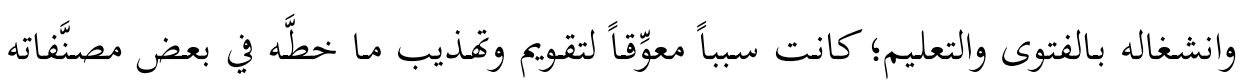

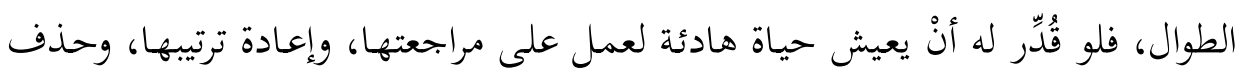

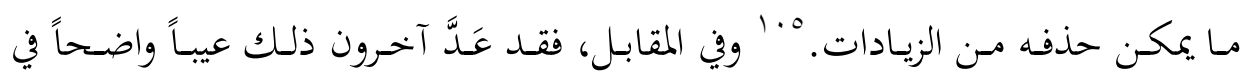

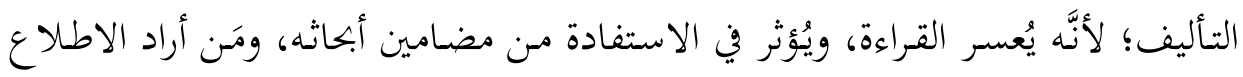

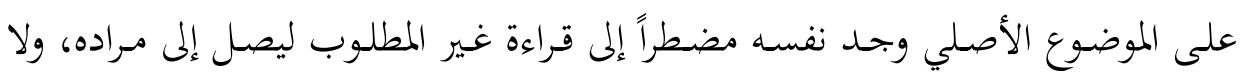

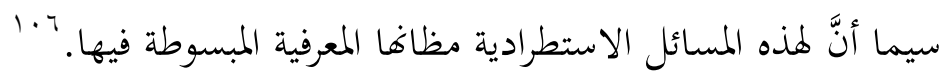

يكتاجون إلى الصعب منها، ولا يروي ظمأهم إلا التفاصيل الدقيقة، ولا يعجبهم إلا الألفاظ الغريبة؛ أي لا يشفي

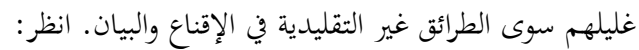

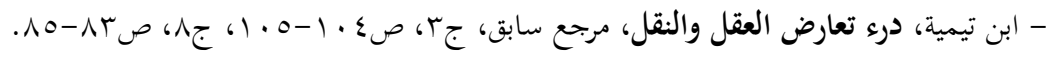

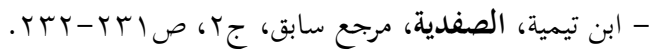

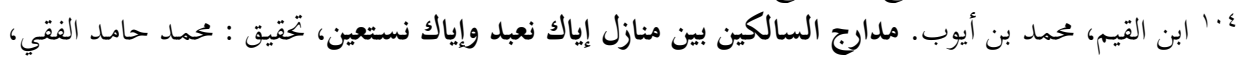

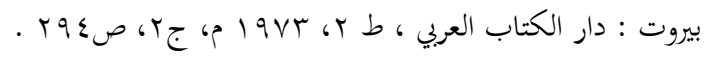

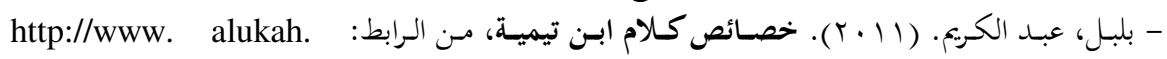

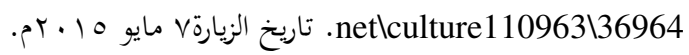

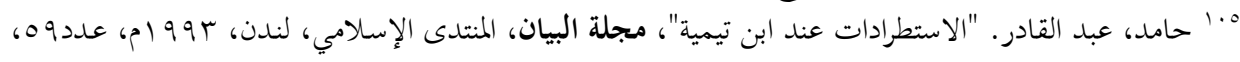

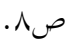

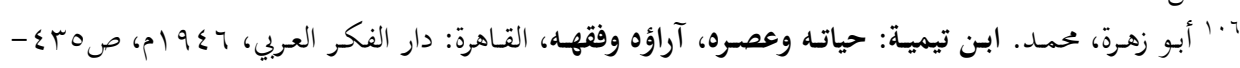
بrع. انظر أيضاً: - عقيلي، إبراهيم. تكامل المـنهج المعرفي عند ابن تيمية، فرجينيا: المعهد العالمي للفكر الإسلامي، طا،

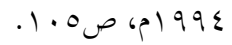




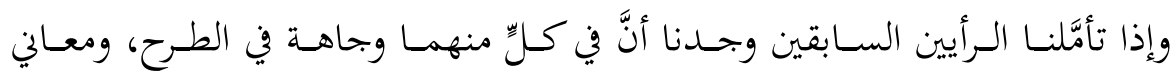

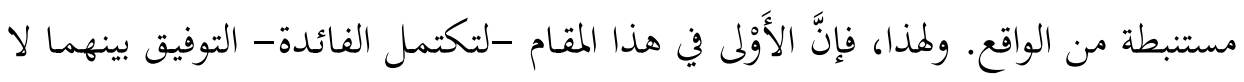

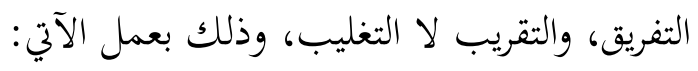
- مراعاة طبيعة القدرات العلمية المتنوعة التي حازهـا ابن تيمية، والتي جعلته أهلاً

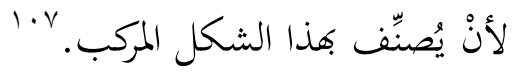
- مراعاة حقيقة الاختلاف في مستوى القدرات المعرفية بين أهل العلم قديماً، وأهل

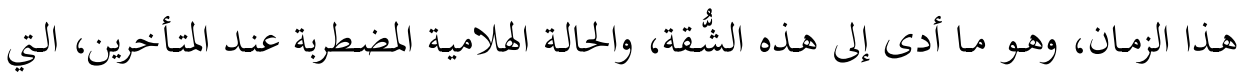

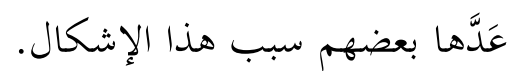

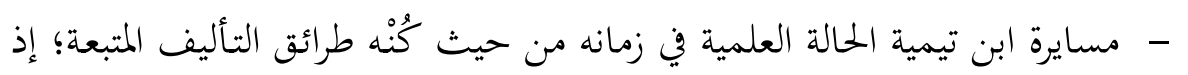

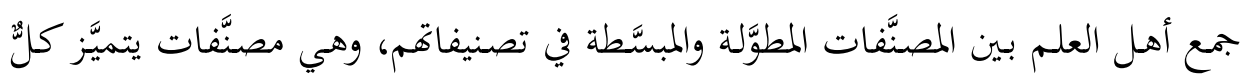
منها بميزات إيجابية وسلبية. - السعي إلى إشباع الرغبات المعرفية، بما في ذلك مبلك مراعاة المستوى العلمي والفكري الرفيع للفئات المستهدفة من شتى المدارس الفكرية حينئذٍ.

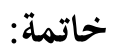

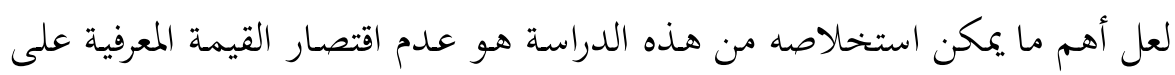

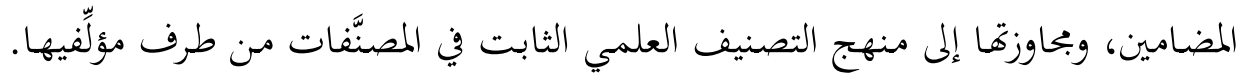

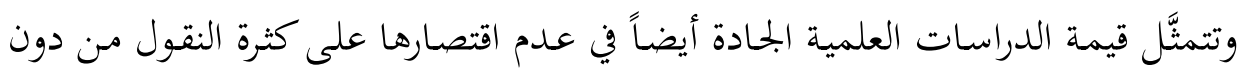

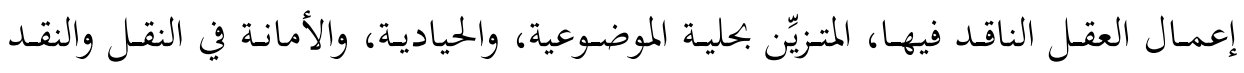
والتحليل والاستنباط.

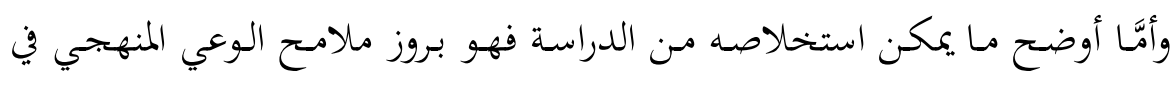

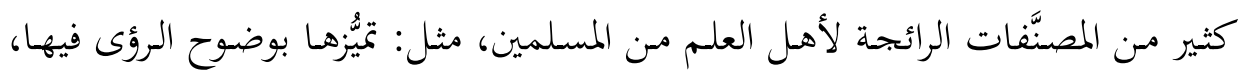

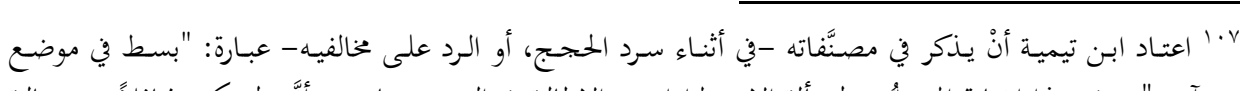

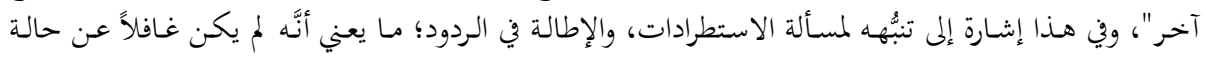
التضخم التي غَيَّت بها بعض مصنَفاته. 
والترابط الفكري لمعانيها، والتدرُّج المعرفي لمضامينها، والتوازن الجحلي في القضايا الخلافية.

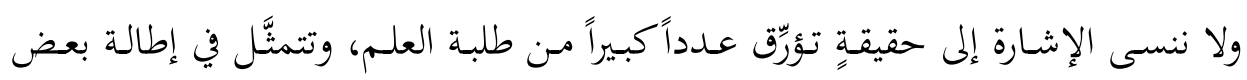

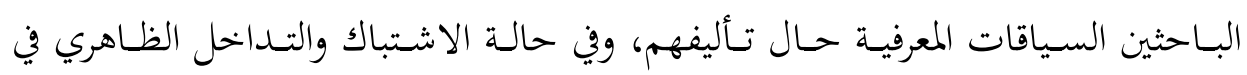

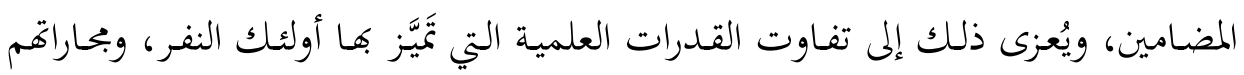
طرائق أهل العلم في زماهم، إضافةً إلى احتمالية توجيه هذه المصنَّفات إلى فئات معينة.

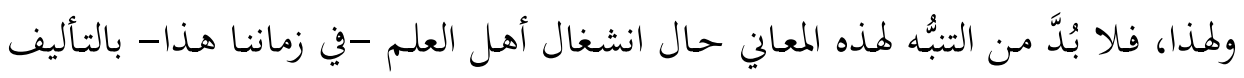

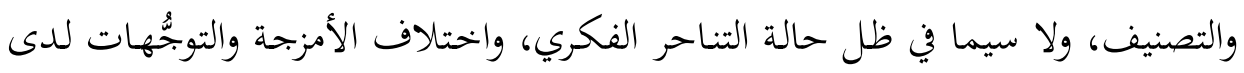

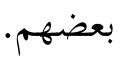

وبالمثل، فلا بُدَّ من التنبُهه لحقيقة أطروحات طلبة العلم، والاجتهاد في تمييز صحيحها من سقيمها بالتثبُّت من صحة المنهج المتبع في أمثال هذه المصنَّنات. 